10 Nordisk

Ministerråd

\title{
VIDEN SOM VIRKER I PRAKSIS
}

Styrket nordisk samarbejde på socialområdet

AF ÁRNI PÁLL ÁRNASON 
VIDEN SOM VIRKER I PRAKSIS

Styrket nordisk samarbejde på socialområdet

Árni Páll Árnason

ANP 2018:821

ISBN 978-92-893-5835-4 (PRINT)

ISBN 978-92-893-5836-1 (PDF)

ISBN 978-92-893-5837-8 (EPUB)

http://dx.doi.org/10.6027/ANP2018-821

ㄷ) Nordisk Ministerråd 2018

Layout: Louise Jeppesen

Omslagsfoto: Johnér

Tryk: Rosendahls

Printed in Denmark

Det nordiske samarbejde

Det nordiske samarbejde er en af verdens mest omfattende regionale samarbejdsformer. Samarbejdet omfatter Danmark, Finland, Island, Norge og Sverige samt Færøerne, Grønland og Åland.

Det nordiske samarbejde er både politisk, økonomisk og kulturelt forankret og er en vigtig medspiller i det europæiske og internationale samarbejde. Det nordiske fællesskab arbejder for et stærkt Norden i et stærkt Europa.

Det nordiske samarbejde ønsker at styrke nordiske og regionale interesser og værdier $i$ en global omverden. Fælles værdier landene imellem er med til at styrke Nordens position som en af verdens mest innovative og konkurrencedygtige regioner.

Nordisk Ministerråd

Nordens Hus

Ved Stranden 18

1061 København K

www.norden.org

Download og bestil nordiske publikationer: www.norden.org/nordpub 


\section{VIDEN SOM VIRKER I PRAKSIS \\ Styrket nordisk samarbejde på socialområdet}





\section{Indhold}

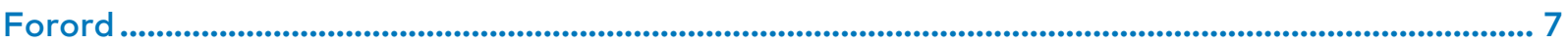

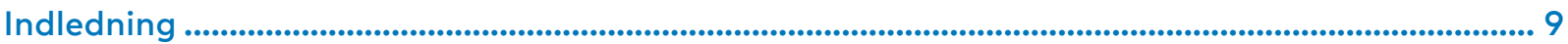

Et mere vidensbaseret og efterspørgselsorienteret

nordisk samarbejde på socialområdet ................................................................................................. 13

1. Systematisk samarbejde om viden og indsatser, der virker, på socialområdet .................................... 13

2. Et mere efterspørgselsorienteret samarbejde ................................................................................................ 14

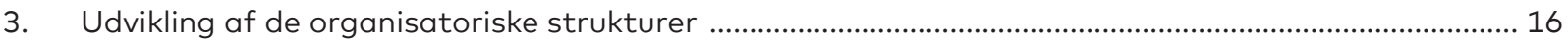

Centrale temaer for nordisk samarbejde på socialområdet ............................................................... 19

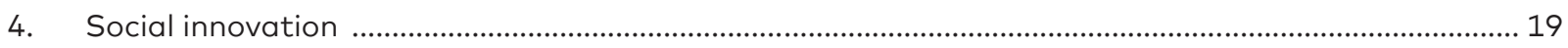

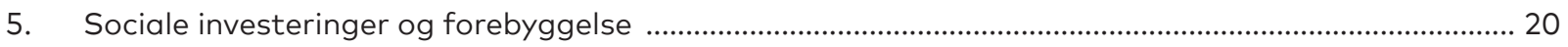

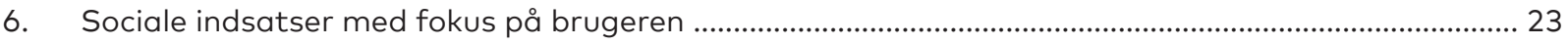

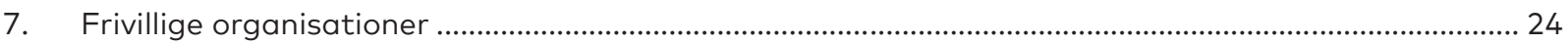

Styrket nordisk samarbejde om børn og unge, udsatte voksne,

ældre og mennesker med handicap .................................................................................................................... 29

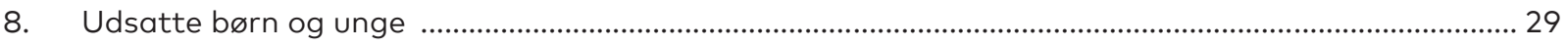

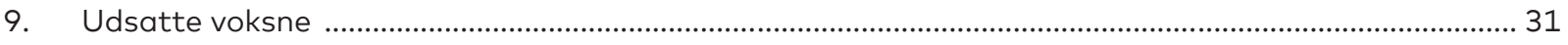

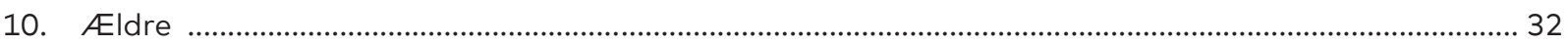

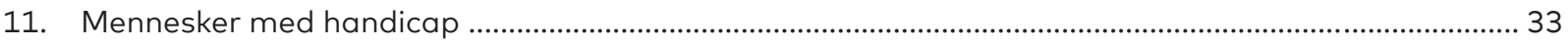

Sociale indsatser i et bredere perspektiv ............................................................................................. 37

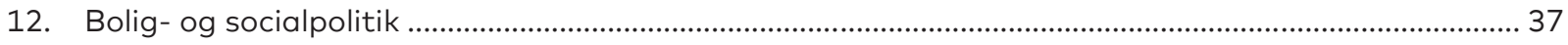

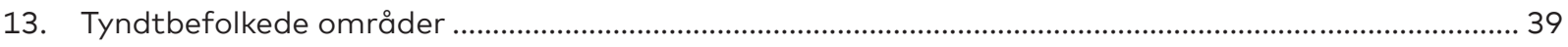

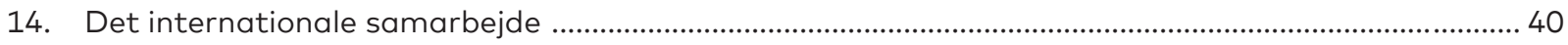




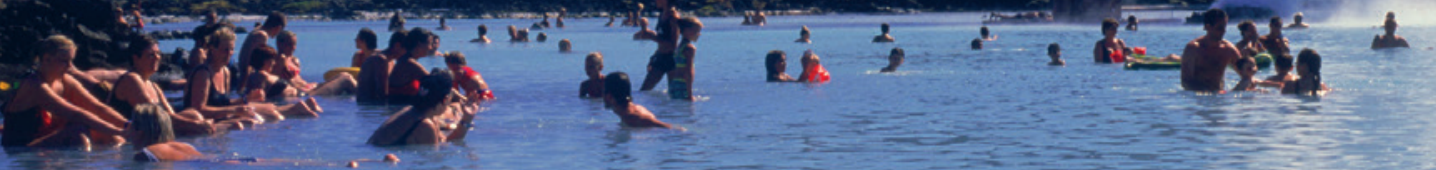
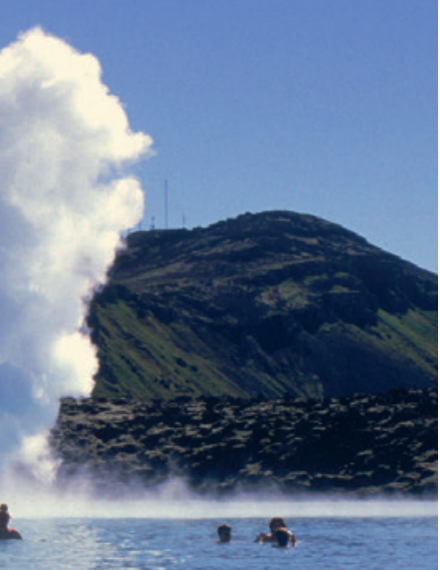

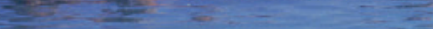

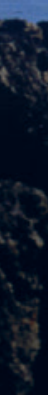

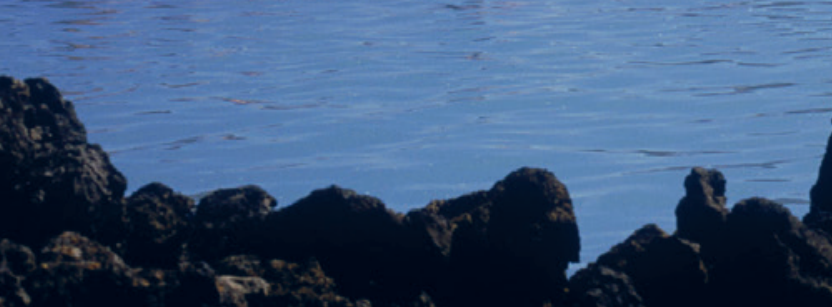

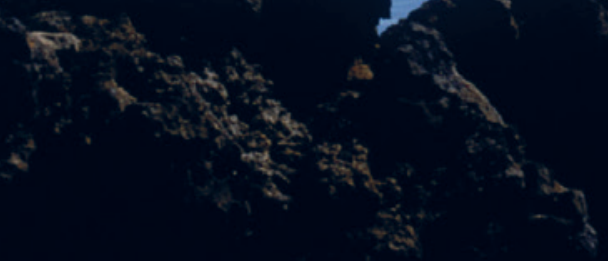

ing

Q
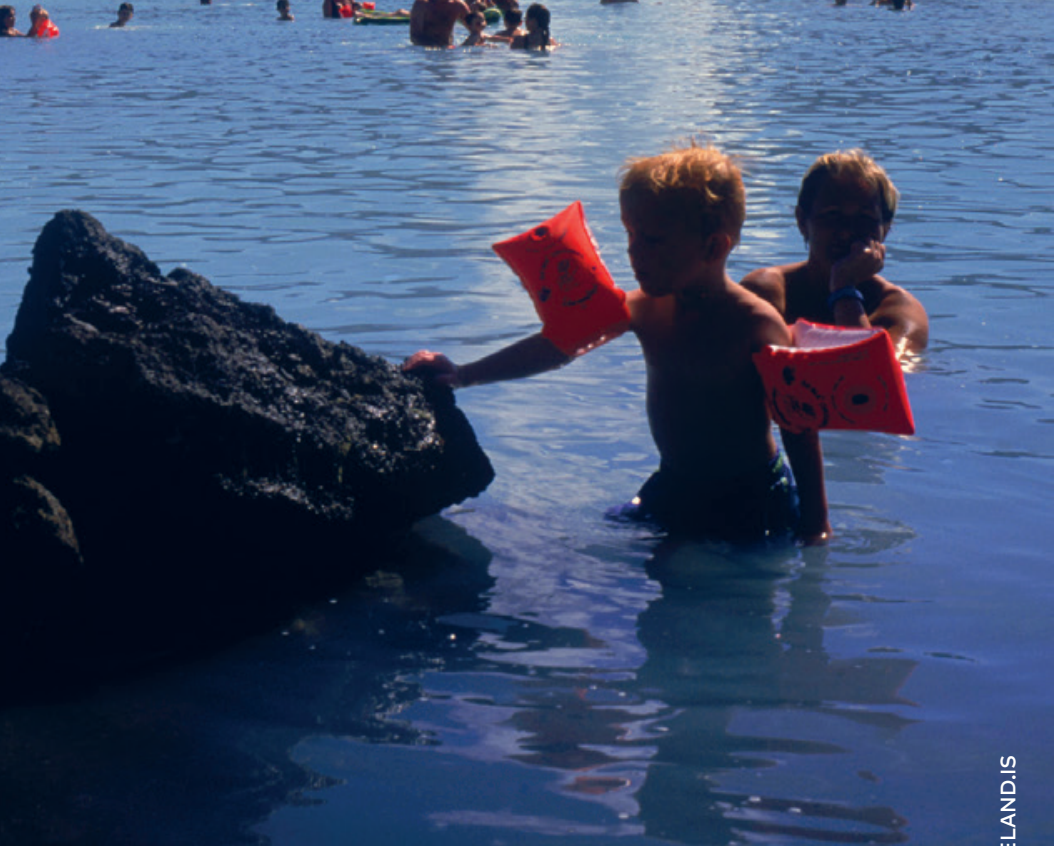


\section{Forord}

Jeg følte mig meget beæret, da jeg af Nordisk Ministerråds generalsekretær Dagfinn Høybråten blev bedt om at stå i spidsen for en strategisk gennemlysning af det nordiske samarbejde på socialområdet, som Nordisk Ministerråd for Socialog Helsepolitik havde besluttet skulle gennemføres.

Socialområdet er en grundlæggende byggesten i den nordiske velfærdsmodel, og som tidligere socialminister og økonomiminister i Island i kølvandet på finanskrisen ved jeg af erfaring, hvor vigtig den nordiske velfærdsmodel er, og at man aldrig må tage den for givet.

Med de udfordringer, som den nordiske velfærdsmodel står over for i dag, blandt andet hvad angår den demografiske udvikling, innovationsmuligheder og de økonomiske forhold i verden, er det helt vomgængeligt at se nærmere på, hvordan det nordiske samarbejde på socialområdet kan styrkes - både for at værne om den nordiske velfærdsmodel og forny den og på den måde bidrage til at sikre den sociale tryghed for borgerne i Norden og forankre Nordens førerposition på området.

Formålet med gennemlysningen af det nordiske samarbejde på socialområdet er at udvikle og styrke det nordiske samarbejde på socialområdet, så det er tilpasset landenes behov og aktuelle problemstillinger samt fører til konkrete resultater. For mig har det været afgørende, at gennemlysningen ikke skulle være en akademisk analyse af muligheder og udfordringer for den nordiske velfærdsmodel eller af socialområdet i de nordiske lande. Jeg har derimod ønsket at udarbejde en handlingsorienteret rapport, som er baseret på en grundig forståelse af de aktuelle udfordringer, vi står overfor, og kommer med konkrete forslag, der kan bidrage til et stærkere samarbejde på socialområdet i Norden.
I forbindelse med mit arbejde med gennemlysningen har jeg besøgt alle de nordiske lande: Danmark, Finland, Island, Norge og Sverige samt Færøerne, Grønland og Åland. Herudover har jeg haft møder med EU-Kommissionen og EUParlamentet i Bruxelles og OECD i Paris. Jeg har regnet ud, at jeg har besøgt over 200 aktører på socialområdet i landene, heriblandt ministre, offentlige myndigheder, forskere, interesseorganisationer og frivillige sociale organisationer. Det har været gode besøg med mange interessante diskussioner, og jeg har fået meget viden, mange idéer og indspil med mig fra disse møder. Det vil jeg gerne sige stor tak for til alle, jeg har mødt.

Det er på baggrund af disse besøg, at jeg i denne rapport fremlægger mit bud på 14 forslag til, hvordan det nordiske samarbejde på socialområdet kan styrkes. Men dette omfang betyder også, at rapporten søger at danne et billede af de store linjer og derfor ikke tager stilling til alt, som jeg har hørt, set og diskuteret. Udvælgelsen af disse forslag og formuleringerne i rapporten er alene mit ansvar.

Jeg vil gerne rette en kæmpestor tak til seniorrådgiver Søren Stokholm Thomsen, seniorrådgiver Kåre Geil og studentermedhjælper Johanna Larby fra Nordisk Ministerråds sekretariat, som har været med hele vejen, hjulpet med tanker og formuleringer og været mig til meget stor hjælp i forbindelse med udarbejdelsen af denne rapport.

\section{God læselyst!}

\section{Árni Páll Árnason}

Stockholm den 16. oktober 2018 


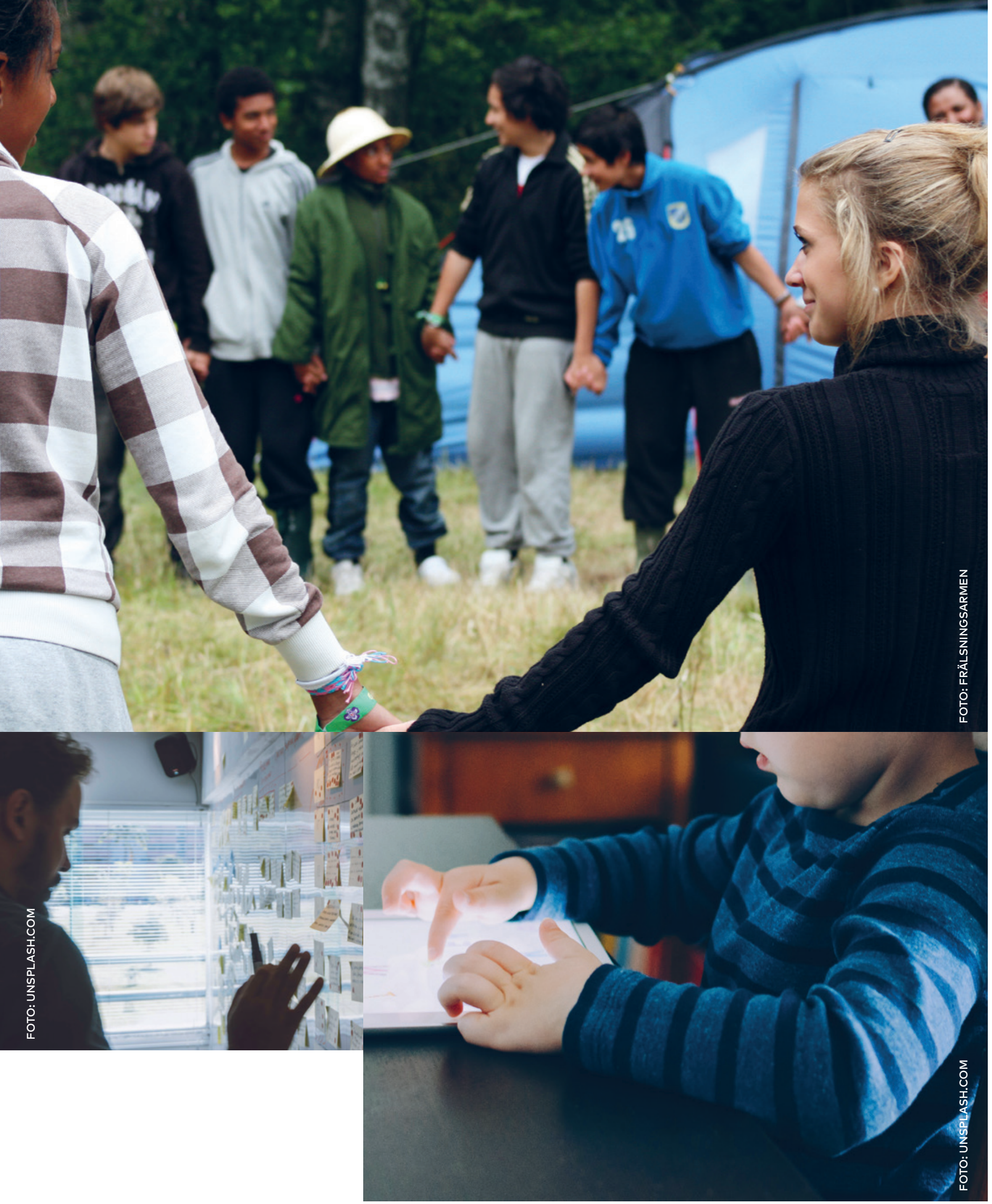




\section{Indledning}

Jeg bliver af og til spurgt, om der findes en nordisk velfærdsmodel. Det er et godt spørgsmål. Norden består af forskellige lande med forskellige historiske udviklinger, der har fort frem til deres nuværende status som velfærdssamfund. På et af de mange møder, som jeg har været til i forbindelse med dette projekt, fik jeg at vide, at en velkendt nordisk politiker engang havde svaret ja til spørgsmålet og derefter tilføjet, at de fem nordiske lande kunne sammenlignes med fem søstre, som hver især har giftet sig med mænd af forskellig nationalitet. Husholdene blev naturligvis forskellige, men der er også meget stærke fælles træk. Måske er det en skrøne, men i mine øjne er det en indsigtsfuld betragtning. Vi gør tingene på hver vores måde, men vi har et tydeligt fælles grundlag: Et solidt udbud af sociale indsatser, universel ret til skattefinansierede velfærdstilbud, et stærkt trepartssamarbejde, en nøglerolle for kommuner i leveringen af velfærdsydelser og et aktivt civilsamfund.

Den nordiske velfærdsmodel har bevist sin relevans og holdbarhed. Den har formået at udrydde sult, fattigdom og sygdom og skabe samfund, som er mere ligestillede end de fleste andre lande, og at give mulighed for større social mobilitet. De samfundsmæssige resultater i de nordiske lande ligger konstant i top i internationale sammenligninger. Men i dag står vi også over for nye og anderledes udfordringer.

Den klassiske velfærdsstat er ofte blevet betragtet som en institution, der fordeler goder og leverer velfærdsydelser udført af betalte fagfolk. Det er til en vis grad korrekt, men velfærdsstaten er også en manifestation af et partnerskab med frivillige kræfter og arbejdsmarkedsparterne. Gennem de seneste årtier er indholdet i og leveringen af velfærdsydelser i stadig stigende grad fastsat og organiseret af de offentlige myndigheder. Dette har haft en lang række fordele, men det har også gjort vores systemer mere rigide og bureaukratiske og mindre fleksible, end vi ønsker, at de skal være. Derudover har det medført, at vores systemer ofte orienterer sig mere i retning af producenten snarere end brugeren, hvilket kan svække vores evne til at gribe hurtigt ind over for nye udfordringer og finde nye løsninger.

Vi kan også se, at mange af de vanskeligste sociale udfordringer, som vi står over for, ikke har én enkelt årsag. Vi ser social isolation og ensomhed som et voksende fænomen i hele samfundet - fra barndom til alderdom. Vi ser eksempler på, at social ulighed og "udenforskab" arves mellem generationer. Alle de nordiske lande har strukturelle svagheder, når det handler om at håndtere komplekse samfundsmæssige udfordringer, som kræver en koordineret indsats på tværs af sektorer, vanset om det gælder sundhed, arbejdsmarked, uddannelse eller boligforhold. Der er alt for mange eksempler på, at der ikke bliver taget hånd om disse udfordringer, og at forsøg på at finde løsninger løber ud i sandet, fordi vores systemer er opbygget i siloer, hvor ingen har ansvaret for at nå frem til en samlet løsning for den enkelte. Og selvom ingen for alvor kan tvivle på den offentlige sektors evne til at tage hånd om mange samfundsmæssige udfordringer, har de offentlige instanser ikke oplagte forudsætninger for at løse problemer med social isolation og ensomhed. Her 
er vi nødt til at udvikle og styrke vores forskellige sociale netværk: familie, venskaber, peerstøtte, frivillige organisationers indsatser og lokalsamfund.

Noget af det mest bemærkelsesværdige, jeg har erfaret i mit arbejde med denne undersøgelse, er det overordnede synspunkt hos alle involverede - fra ministre til embedsmænd, frivillige organisationer og brugere - at vi har et alt for mangelfuldt videngrundlag for de sociale indsatser. Vi mangler viden om, hvad der virker, vi mangler strategier for, hvordan vi systematisk kan integrere nye og bedre metoder i vores sociale tilbud, og vi mangler procedurer for, hvordan vi skal holde op med at anvende de indsatser, der ikke virker. Der er brug for, at vi erkender - særligt når vi ser på den sociale sektor i forhold til andre sektorer - vigtigheden af at investere i de sociale tiltag og dermed også i at investere i at udvikle og anvende viden om, hvad der virker.

Denne mangel på et stærkt videnbaseret udgangspunkt for vores sociale velfærdsløsninger er et velkendt fænomen i hele den vestlige del af verden. Historisk set har man blandt andet skudt skylden for dette på behovet for at gribe hurtigt ind, hvorfor der ikke er tid til at afprøve forskellige løsninger, og på politikeres frygt for at blive udpeget som handlingslammede, mens forskellige løsninger prøves af. Opbygning af kompetence om evaluering og effektmåling på socialområdet og teknologiske fremskridt har dog gjort det meget nemmere for os at afprøve forskellige løsninger, og platformsøkonomien giver inspiration til og muligheder for at videreudvikle borgerinitiativer og løsninger udarbejdet af civilsamfundet. De største udfordringer, som vi står over for i dag, er desuden så komplekse, at de mulige løsninger kan vise sig at være for dyre og for ineffektive, hvis vi ikke formår at teste dem og udvikle dem gradvist. De nordiske lande har mange ligheder og fælles værdier inden for socialpolitikken, og vi har derfor rig mulighed for i fællesskab at afprøve forskellige løsninger og hjælpes ad med at udbrede dem, der virker, og dermed komme fri af dem, der ikke virker. I vore dage har vælgerne heller ikke meget til overs for politikere, der tror, at de har svar på alt, men i virkeligheden ikke har svar på noget som helst. Vi har meget at vinde på at forankre politik og politiske løsninger i evidens og fakta - især hvis alternativet er at træffe beslutninger på baggrund af forudfattede meninger.

For at gøre dette effektivt er vi nødt til at være mere åbne over for social innovation i vores systemer og bestræbe os på at samarbejde om at opbygge en stærk begrebsramme for innovativ tænkning og udveksle viden og erfaringer internt i Norden. Vi skal fortsætte arbejdet med at udvikle og afprøve indsatser og give nye, virksomme indsatser bedre forudsætninger for at finde vej og fodfæste i vores systemer. Gør vi ikke det, risikerer vi at blive overhalet af andre. Over hele verden er der lande, der vokser sig økonomisk stærkere og får større og større velfærdsbehov, men som ikke er velsignet eller bebyrdet - med strukturer, der har flere årtier på bagen. Disse lande er allerede i gang med at eksperimentere, afprøve forskellige løsninger og benytte nye værktøjer som for eksempel social bonds til at opbygge partnerskaber, som understøtter, at man bruger penge på de løsninger, der virker.

Vi er nødt til at bruge de værdier, erfaringer og traditioner, som vi har opbygget i vores systemer, og systematisk fjerne de hindringer, der står i vejen for vores enorme humankapital, så vi kan bruge den til at udvikle og afprøve nye løsninger. Vi er også nødt til at gøre brug af de ressourcer, der findes i de frivillige organisationer, og ruste dem yderligere til at magte den svære opgave, som det er at levere velfærdsservices, og inddrage de værdifulde sociale netværk, som de frivillige organisationer er baseret på, og den fleksibilitet, som de kan bidrage med i udviklingen af løsninger. 
Vi må ikke være bange for denne udfordring eller føle, at innovation er ensbetydende med, at man vender vores historie ryggen - tværtimod må vi huske, at vores velfærdsmodeller er opstået som innovative løsninger på datidens kæmpe udfordringer og fortsat kræver innovative indsatser.

Den første del af min rapport fokuserer på forslag til, hvordan vi kan styrke det nordiske samarbejde på socialområdet gennem et mere systematisk samarbejde om deling og udveksling af viden og erfaringer, samt hvordan vi kan sikre en mere efterspørgselsorienteret tilgang til de nordiske initiativer. Det nordiske samarbejde på socialområdet kan levere meget mere til landene, end tilfældet er i dag, og et mere systematisk og efterspørgselsorienteret samarbejde på socialområdet kan give landene et bedre og større bidrag til det nationale udviklingsarbejde.

Anden del fokuserer på centrale temaer for nordisk samarbejde på socialområdet i form af samarbejde om social innovation, social investering og forebyggelse samt om styrket brugerfokus og -inddragelse. Endelig indgår forslag om at styrke det nordiske samarbejde med frivillige organisationer på det sociale område.

Systematisk vidensopsamling og erfaringsudveksling har stor betydning for bedre sociale indsatser, ikke mindst når det gælder børn og unge, udsatte voksne, mennesker med funktionsnedsættelser og ældre. På mine mange møder rundt omkring i landene er det noget, der især har optaget de mange forskellige aktører inden for området, som jeg har talt med. Det er klart, at forslagene i de to første dele af rapporten netop tager sigte på at styrke indsatserne i forhold til disse målgrupper. Ikke desto mindre har jeg fundet det nødvendigt, og er af mine mange besøg i landene blevet inspireret til, at stille forslag om nordisk samarbejde om indsatser for de enkelte grupper. Disse forslag fremgår af rapportens tredje del.

Jeg er ved mine besøg i landene blevet opmærksom på og har fundet det vigtigt, at sociale indsatser skal ses i et bredere perspektiv. I sidste del af min rapport kommer jeg derfor med forslag til samarbejde på boligområdet og om tyndtbefolkede områder i Norden samt forslag om internationale dimensioner af det nordiske samarbejde på socialområdet. Uddannelse, helbredsforhold og arbejdsforhold har jeg i et vist omfang forsøgt at adressere inden for de enkelte målgrupper, men det er klart, at disse sektorområder også spiller en rolle i de socialpolitiske indsatser generelt. Jeg vil derfor opfordre til, at man i Nordisk Ministerråd for Social og Helsepolitik, hvor det er relevant, inddrager og samarbejder med andre ministerråd i nordisk regi, når man skal drøfte og udføre mine anbefalinger i denne rapport. 


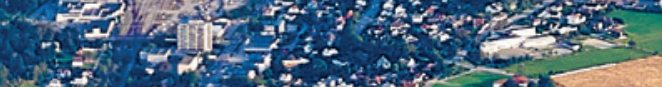

20

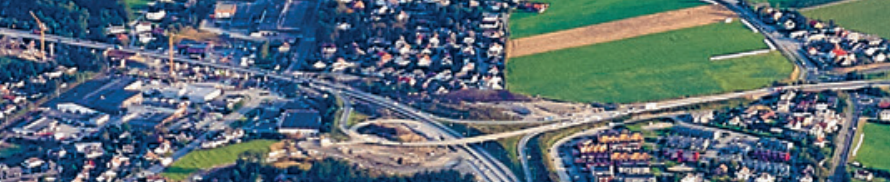

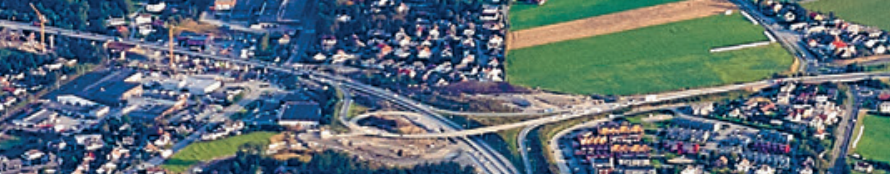

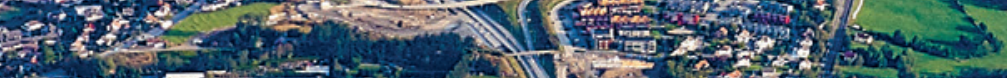

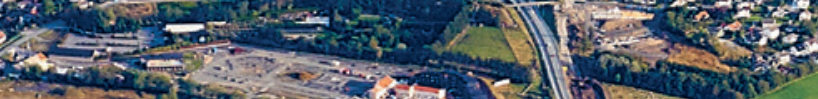
s. $15 \times-x^{15}$ NWt

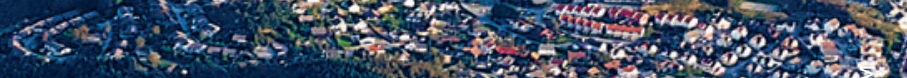
1
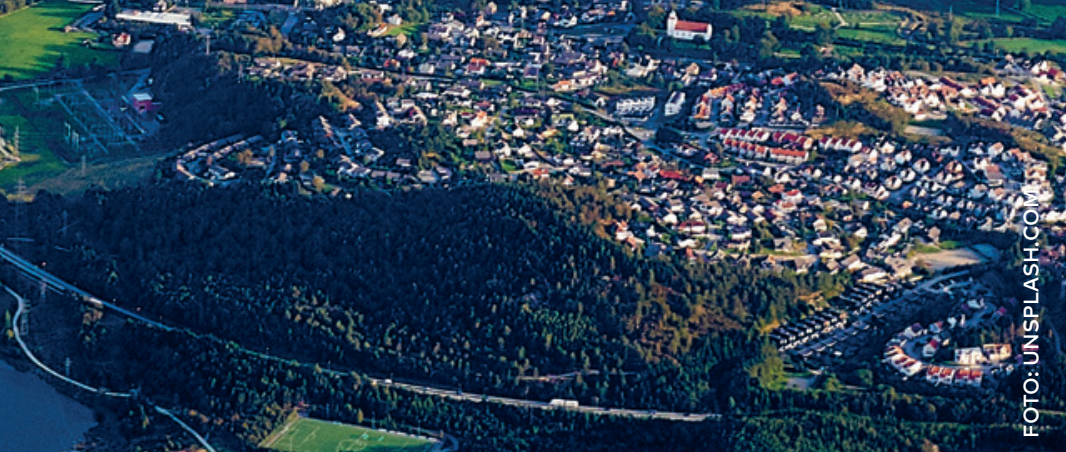


\section{Et mere vidensbaseret og efterspørgsels- orienteret nordisk samarbejde på social- området}

Arbejdet med denne gennemlysning af det nordiske samarbejde på socialområdet har vist, at der hos aktører på socialområdet i de nordiske lande er et stort ønske om at styrke det nordiske samarbejde om viden og indsatser, der virker, og gøre det nordiske samarbejde mere efterspørgselsorienteret. Der er et ønske om, at resultaterne af det nordiske samarbejde i højere grad skal kunne anvendes i udviklingsarbejdet på socialområdet i de enkelte nordiske lande og på Færøerne, Grønland og Åland. I den forbindelse er det vigtigt at se på, om de organisatoriske strukturer for det nordiske samarbejde på socialområdet bedre kan underbygge og styrke dette ønske og dermed løfte det nordiske samarbejde på socialområdet til et højere niveau, end det er i dag, til gavn for landene og borgerne i Norden.

I det følgende fremgår derfor forslag til, hvordan det nordiske samarbejde på socialområdet kan gøres mere efterspørgselsorienteret, og hvordan det nordiske samarbejde kan gøres mere systematisk, når det gælder arbejdet med viden og indsatser, der virker. I den forbindelse anbefales det også at se på, hvordan de organisatoriske ressourcer, som det nordiske samarbejde har til rådighed $i$ form af institutionelle strukturer, kan understøtte dette arbejde.

FORSLAG 1: SYSTEMATISK SAMARBEJDE OM VIDEN OG INDSATSER, DER VIRKER, PÅ SOCIALOMRÅDET

Der efterspørges fra alle lande mere viden om, hvad der virker, og i flere år har landene arbejdet systematisk med at udvikle viden og afprøve metoder på socialområdet. I dag leverer det nordi- ske samarbejde imidlertid et forholdsvis beskedent og noget ad hoc-præget bidrag til landenes nationale initiativer om vidensbasering af de sociale indsatser. Der er store uudnyttede potentialer ved et nordisk samarbejde om viden på socialområdet, som kan frigøres, hvis samarbejdet gribes mere systematisk an og knyttes tæt til landenes centrale aktører på feltet.

Det nordiske samarbejde på socialområdet bør være en attraktiv platform for landenes centrale aktører som eksempelvis styrelser/direktorater og sektorforskningsinstitutioner, som de kan anvende til at udveksle viden samt til at drøfte forslag til konkrete, nordiske initiativer, som kan supplere de nationale indsatser, når det gælder viden om sociale indsatser, der virker. En særlig merværdi består eksempelvis i afprøvning af indsatser for relativt små målgrupper, hvor målgruppen er for lille til, at man effektivt kan foretage afprøvninger. Her vil et samarbejde blandt andet kunne bidrage med fælles afprøvninger af interventioner.

Et nordisk samarbejde om viden om indsatser, der virker, kan med fordel også omfatte erfaringsudveksling om vellykket implementering i praksis på socialområdet. Der er i direktorater, myndigheder, forskningsinstitutioner og faglige selskaber i og uden for Norden opbygget solid viden om effektiv implementering. Der kan i denne sammenhæng også sættes fokus på, hvordan man tilsvarende bedst udfaser de indsatser, der ikke virker. 
En række initiativer og samarbejdsformer på området kan overvejes:

- At der i relevante fora, eksempelvis det foreslåede Forum for Nordisk Samarbejde på Socialområdet, som fremgår af forslag 2, eller lignende nordiske højniveaumøder, løbende orienteres om centrale tiltag i landene om udvikling og afprøvning af konkrete interventioner for målgrupper på socialområdet. Dette kan samtidig være en platform, hvor landene kan drøfte mulige nordiske initiativer om udvikling, afprøvning og deling af viden om interventioner, der virker, som kan præsenteres for Nordisk Ministerråd for Social- og Helsepolitik og Nordisk Embedsmandskomité for Social- og Helsepolitik eller fortsætte i bilaterale samarbejder.

- Etablering af netværk for nationale sektorforskningsinstitutioner og tilsvarende, som kan understøtte etablering af fælles initiativer om afprøvning af metoder, forskningssamarbejde mv.

- Erfaringsudveksling om og eventuelt udvikling af fælles metoder til dokumentation og videreudvikling af lovende social praksis, som udviser potentiale, men endnu ikke er afprøvet og dokumenteret.

- Fælles afprøvning af og effektforskning i interventioner på tværs af nordiske lande med henblik på at opnå større målgrupper.

- Anvendelse af det nordiske samarbejde som en platform for at indhente forskningsbaseret viden fra lande uden for Norden, herunder eksempelvis gennem fælles nordisk finansiering af metastudier om effekten af sociale interventioner.

- Videreudvikling af det eksisterende nordiske samarbejde mellem internetportaler, der formidler viden på socialområdet til kommuner og udførere på socialområdet.

\section{FORSLAG 2: ET MERE EFTERSPØRGSELS- ORIENTERET SAMARBEJDE}

Det nordiske samarbejde har et stort potentiale til at levere konkrete bidrag til landenes nationale udviklingsarbejde på socialområdet. Men dette potentiale udnyttes ikke i tiltrækkelig grad. Der foretages i dag ikke en samlet, løbende og systematisk afdækning af, hvad landenes centrale aktører på socialområdet ønsker, at det nordiske samarbejde skal bidrage med. Dette indebærer en risiko for, at de nordiske initiativer ikke leverer det, der er brug for, og at vigtige potentialer for samarbejde ikke udnyttes.

Nordiske initiativer udføres i sagens natur på tværs af flere landes forvaltningstraditioner og organisatoriske strukturer. Det er vigtigt at undgå, at man i søgen efter kompromiser ikke ender med produkter, der fungerer i en nordisk "logik", men som ikke er tæt på den virkelighed, som landene arbejder i. Der er derfor brug for, at de produkter, som det nordiske samarbejde udarbejder, og formidlingen heraf, knyttes stærkere til de nationale strukturer for udvikling og formidling af viden på socialområdet.

En mere efterspørgselsorienteret tilgang, hvor centrale nationale aktører mere systematisk inddrages og bidrager til at formulere landenes efterspørgsel efter nordisk samarbejde, vil kunne fremme kvaliteten og relevansen af de nordiske samarbejdsinitiativer. Det nordiske samarbejde på socialområdet bør samlet set styrkes i forhold til både identifikation af efterspørgsel, design af de konkrete projekter og forventede leverancer samt formidling af viden og resultater. 


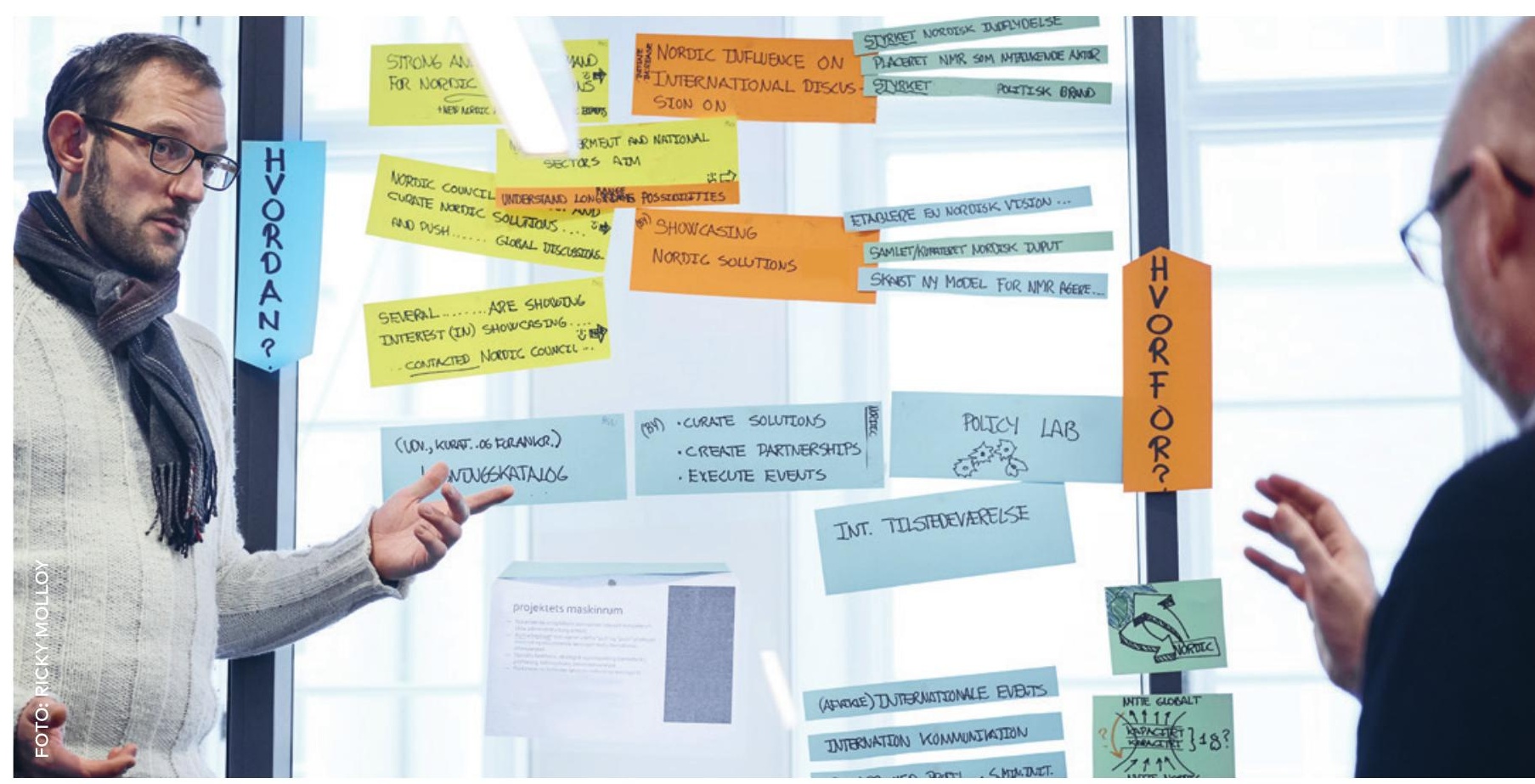

\section{Forum for nordisk samarbejde på socialområdet}

Det foreslås, at der etableres et Forum for Nordisk Samarbejde på Socialområdet. Forummet skal løbende identificere landenes efterspørgsel efter nordisk samarbejde på socialområdet og på denne baggrund formulere forslag til Nordisk Ministerråd for Social- og Helsepolitik og Nordisk Embedsmandskomité for Social- og Helsepolitik om nordiske initiativer i regi af Nordisk Ministerråd. Forummet bør have deltagelse af de relevante departementer og direktorater fra landene samt Færøerne, Grønland og Åland. Forummet kan eksempelvis sekretariatsbehandles af Nordens Velfærdscenter i et samarbejde med Nordisk Ministerråds sekretariat. Forum for Nordisk Samarbejde på Socialområdet kan efter behov suppleres af højniveaumøder eller tilsvarende på udvalgte delområder på socialområdet, for eksempel børneområdet.

\section{Bedre involvering af nationale aktører $i$ design af initiativer}

Det foreslås, at det i regi af Forummet og Nordisk Embedsmandskomité for Social- og Helsepolitik drøftes, hvordan man bedre kan involvere relevante aktører, når konkrete nordiske initiativer skal udformes. Det bør herved bedre understøttes, at der ved design af et nordisk initiativ er et tydeligt billede af initiativets målgruppe ( $f x$ direktorater i landene) og målgruppens efterspørgsel, hvilken type leverance målgruppen efterspørger, og at der opnås et ejerskab til initiativet hos relevante parter. Dette bør omfatte alle initiativer i regi af Nordens Velfærdscenter, formandskabsprojekter samt øvrige initiativer i sektoren, som besluttes af Nordisk Ministerråd for Social- og Helsepolitik/Nordisk Embedsmandskomité for Social- og Helsepolitik og koordineres af Nordisk Ministerråds sekretariat. 


\section{Formidling og kommunikation af viden fra nordiske projekter}

Der bør gennemføres initiativer, som fremmer, at formidling af viden fra nordiske initiativer, herunder formidling af viden fra Nordens Velfærdscenter, knyttes stærkere til den nationale formidling af viden på socialområdet. Allerede når et nordisk initiativ designes, bør det tænkes ind, hvordan initiativets resultater konkret skal indgå i de "vidensbaser" og kanalstrategier, som anvendes i landene til at formidle aktuelt bedste viden til kommuner og leverandører og andre aktører på socialområdet. Eksempelvis findes der i landene centrale internetportaler, som på nationalt niveau formidler aktuelt bedste viden på socialområdet og særligt på børn- og ungeområdet til kommuner og andre udførere, eksempelvis Vidensportalen i Danmark, Metodguiden i Sverige, Ungsinn i Norge og Kasvuntuki i Finland. Nordisk Embedsmandskomité for Social- og Helsepolitik har allerede besluttet at give støtte til et samarbejde mellem disse portaler, og det kan i tillæg hertil overvejes, om disse og lignende formidlingstiltag i landene i højere grad kan anvendes til formidling af viden fra de nordiske projekter.

Det foreslås desuden, at der løbende tages stilling til, hvordan vidensprodukter fra konkrete initiativer i højere grad kan gøres relevante for aktører i de nordiske lande, der ikke anvender et skandinavisk sprog som arbejdssprog. Dette kan eksempelvis gøres ved i højere grad at inkludere oversættelse til engelsk. Herved vil produkter fra det nordiske samarbejde på socialområdet også i højere grad kunne anvendes i samarbejdsrelationer uden for Norden.

\section{FORSLAG 3: UDVIKLING AF DE ORGANISATORISKE STRUKTURER}

For at understøtte udmøntningen af de foregående forslag er det vigtigt, at de organisatoriske ressourcer, som det nordiske samarbejde på socialområdet har til rådighed i form af institutioner og samarbejdsorganer, kan bidrage til et mere efterspørgselsorienteret samarbejde med fokus på viden om indsatser, der virker. Det er derfor nødvendigt at se på, hvordan sektorens to vidensproducerende og -koordinerende organisationer, Nordens Velfærdscenter og Nordisk Socialstatistisk Komité (NOSOSKO), bedre kan imødekomme landenes efterspørgsel efter nordisk samarbejde.

\section{Nordens Velfærdscenter}

Nordens Velfærdscenter (NVC) har i en række konkrete projekter leveret relevante og anvendelige produkter og tjenester i form af for eksempel netværk og seminarer. Det vurderes dog, at potentialet i institutionen kan udnyttes bedre, end det er tilfældet i dag. En række forhold er relevante at tage i betragtning i forhold til den videre udvikling af NVC.

Udvælgelsen af de fagområder, som NVC arbejder med, samt designet af konkrete projekter udført af NVC, initieres i dag i relativt høj grad af NVC, ligesom der af historiske årsager er særligt fokus på bestemte fagområder frem for andre. For at understøtte, at NVC's arbejde er i samklang med landenes aktuelle efterspørgsel efter nordiske initiativer, bør landenes muligheder for at påvirke NVC's generelle arbejde styrkes, ligesom institutionens arbejde med at designe konkrete projekter i NVC kan udvikles. 
Det foreslås, at der gennemføres en proces, der skal munde ud i mere tydelige krav til, hvilke leverancer der ønskes fra NVC, herunder en mere præcis beskrivelse af institutionens roller og opgaver. Det foreslås samtidigt, at der i samspil mellem Nordisk Embedsmandskomité for Social- og Helsepolitik, Nordisk Ministerråds sekretariat og NVC's ledelse gennemføres en proces, der skal gøre styringen af NVC mere transparent og effektiv i forhold til at levere det, som landene efterspørger.

Landene arbejder meget systematisk med vidensbasering af indsatserne på socialområdet. Landenes fagmiljøer i for eksempel styrelser og direktorater stiller eksempelvis veldefinerede krav til, hvornår en indsats kan anses som veldokumenteret med afsæt i forskning og/eller velbeskrevet praksis. For at være en legitim aktør i dette landskab skal NVC i højere grad kunne sikre, at NVC's leverancer lever op til disse krav.

Der kan med fordel desuden skabes klarere forventninger til NVC's opgave og rolle set i lyset af, at landene har specialiserede fagmiljøer i blandt andet styrelser/direktorater, forskningsinstitutioner og videnscentre, som med fordel kan bringes mere direkte i spil i det nordiske samarbejde på socialområdet, for eksempel med NVC i en styrket rolle som bestiller.

Det foreslås således, at NVC udvikler sine produkter og sine arbejdsgange, så der er en større sammenhæng med landenes prioriteringer i regi af Nordisk Ministerråd for Social- og Helsepolitik og Nordisk Embedsmandskomité for Social- og Helsepolitik, de nationale udviklingsarbejder på socialområdet samt de nationale formidlingsstrategier og kommunikationskanaler for viden på socialområdet.

\section{Nordisk Socialstatistisk Komité (NOSOSKO)}

Det nordiske samarbejde om sammenlignende statistik i samarbejdsorganet NOSOSKO, som har repræsentanter fra myndigheder og statistiske bureaver i landene, blev etableret i 1946 og er en af de ældste former for samarbejde inden for det nordiske samarbejde. Der udføres et omfattende og vigtigt arbejde i komitéen, men der ses potentialer i forhold til at styrke sammenhængen til Nordisk Ministerråd for Social- og Helsepolitik/Nordisk Embedsmandskomité for Social- og Helsepolitiks prioriteringer og øvrige nordiske initiativer, ligesom anvendelsen af NOSOSKOs leverancer synes at kunne fremmes.

Det foreslås, at det vurderes, om der er behov for at justere NOSOSKOs mandat med det formål at understøtte, at NOSOSKOs produktion modsvarer landenes aktørers efterspørgsel efter sammenlignende nordisk statistik. I denne sammenhæng er det værd at erindre, at der, da NOSOSKO blev stiftet, var et stærkt fokus på input i velfærdssystemerne, og at NOSOSKO tilsvarende gennem årene har leveret et godt svar herpå gennem statistik om udgifter på velfærdsområdet og sociale ydelser. Imidlertid ligger fokus i socialpolitikken i dag i højere grad på socialpolitikkens effekter. Det kan derfor være interessant at overveje, om NOSOSKO i højere grad kan bidrage til nordiske samarbejder, der undersøger effekten af sociale initiativer og organiseringer på socialområdet. Der kan ved samme lejlighed ses på, hvordan NOSOSKOs arbejde kan knyttes tættere til det nordiske samarbejde på socialområdet generelt, herunder i form af bidrag til aktuelle initiativer, samt til andet nordisk statistisk samarbejde eksempelvis i regi af Nordregio. 


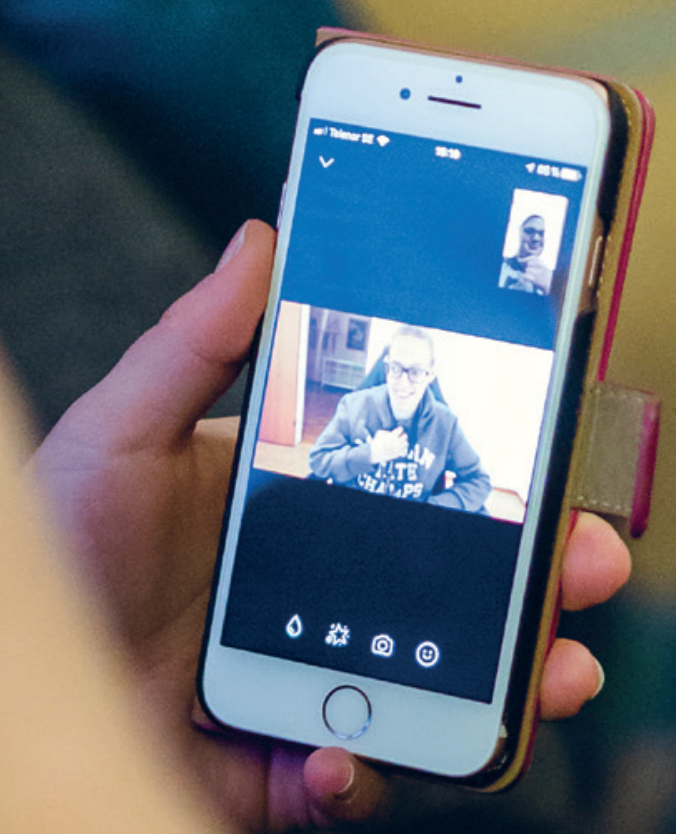




\section{Centrale temaer for nordisk samarbejde på socialområdet}

Et nordisk bidrag til at gøre de sociale indsatser mere vidensbaserede bør også handle om at udvikle nye idéer og fremme tværsektorielle indsatser, der tager udgangspunkt i brugernes ønsker og behov. I dette kapitel fremgår forslag til at styrke det nordiske samarbejde på socialområdet ved at fokusere på social innovation og sociale investeringer med henblik på at bidrage til at gøre vores sociale systemer mere fleksible, åbne for innovation og styrke deres fokus på brugerne. Frivillige organisationer kan her spille en væsentlig rolle i udviklingen af indsatser på socialområdet, da de ofte kan bidrage med indsatser, som er svære at udføre i offentligt regi. Der er derfor også en række forslag til, hvordan de frivillige organisationer kan inddrages i de nordiske initiativer på socialområdet.

\section{FORSLAG 4: SOCIAL INNOVATION}

Blandt aktørerne i den sociale sektor er der bred enighed om, at der er behov for et stærkere vidensgrundlag for socialpolitikken og de sociale indsatser. En del af vejen hertil er at lægge langt større vægt på social innovation og understøtte, at nye, virksomme indsatser systematisk bliver udbredt. Social innovation handler her om at styrke de sociale indsatser ved at udvikle nye idéer og tilbud, som adresserer sociale problemstillinger, og som er mere effektive end de løsninger, der i forvejen eksisterer, herunder eksempelvis ved at skabe nye sociale relationer eller partnerskaber.

I de seneste år er der i de nordiske lande sket en væsentlig udvikling på det sociale område, hvor der arbejdes målrettet og systematisk med udvikling, afprøvning og implementering af virksomme ind- satser, ligesom landene på forskellig vis har iværksat initiativer, der skal fremme social innovation.

Men der er mere at gøre, for vores strukturer er ikke altid egnede til at fremme social innovation og til at indoptage nye, effektive løsninger. Tværtimod kan vores systemer have en indbygget bias $\mathrm{i}$ forhold til de eksisterende, offentligt producerede løsninger, særligt hvis der er en grad af sammenfald mellem de funktioner, der definerer behovet for en løsning, udarbejder løsningerne, administrerer dem og evaluerer resultaterne. Samtidigt stilles der generelt strenge krav til dokumentation af nye løsningers effekter, mens de eksisterende tilbud ikke afprøves med samme konsekvens. Risikoen er, at vi på trods af, at vi gerne vil fremme social innovation, i høj grad bliver ved med at producere det, vi hele tiden har produceret, og at vi undervurderer behovet for forandring.

Der er en række udfordringer, som kan lægge en begrænsning på udvikling af nye indsatser gennem social innovation, og som bør adresseres. Blandt andet er de ressourcer, der afsættes til forskning og innovation på det sociale område, fortsat mindre end i de fleste andre sektorområder. Og mange nye indsatser er udviklet på baggrund af tidsbegrænset projektfinansiering, hvor der, selvom der har kunnet påvises en positiv effekt, ikke efterfølgende afsættes penge til at opretholde og udbrede indsatsen, når finansieringen løber ud.

Derudover ses eksempler på interessante og innovative løsninger udviklet af sociale entreprenører og frivillige sociale organisationer, som ikke får den 
nødvendige støtte til at blive testet og anerkendt, så de kan bruges uden for rammerne af et lille pilotprojekt. Der ses også eksempler på vellykkede initiativer, som er blevet afprøvet og har skaleringspotentiale, men som ikke er blevet samlet op af de offentlige myndigheder. Selvom nye tiltag viser sig at give effekt, kan vores systemer således holde fast i løsninger, der giver dårligere resultater.

Over hele verden oplever vi et øget fokus på social innovation. I det meste af Vesten satte man større fokus på social innovation efter finanskrisen for at opmuntre til at spare penge og opnå bedre resultater for de samme eller færre midler. I andre dele af verden er drivkraften bag social innovation den tiltagende økonomiske styrke i lande, der oplever voksende velstand og stigende velfærdsbehov. Det interessante ved de sidstnævnte eksempler er, at disse lande ikke i lige så høj grad som de nordiske lande er velsignet - eller bebyrdet - med eksisterende strukturer for at levere sociale indsatser. Dermed er de mere frie til at tænke det utænkelige og finde på nye og innovative måder at håndtere nye udfordringer på.

Set i lyset af dette er vi nødt til at give de kompetente og erfarne mennesker, der arbejder på det sociale område, bedre muligheder for at komme med nye idéer og prøve anderledes løsninger. Social innovation skal være en integreret del af vores arbejde, præcis som innovation er det $\mathrm{i}$ mange andre dele af vores økonomi. De nordiske lande er med rette stolte over deres velfærdsmodeller. Disse opstod som innovative projekter og kræver løbende innovation for at blive ved med at være stærke og for at blive ved med at være relevante for verden omkring os.

Det foreslås, at det nordiske samarbejde fremmer innovation på socialområdet gennem:
- et samarbejde mellem Nordisk Ministerråd for Social- og Helsepolitik og Nordisk Ministerråd for Bæredygtig Vækst om, hvordan man kan bruge de eksisterende innovationsstrukturer i de respektive lande samt den nordiske institution Nordic Innovation til effektivt at opmuntre til og støtte innovation på det sociale område.

- oprettelsen af en nordisk pris for social innovation, eksempelvis i form af samarbejde med Nordisk Råd om oprettelse af en Nordisk Social Innovationspris, som uddeles én gang om året sammen med de øvrige nordiske priser for litteratur, musik, film og miljø. Prisen skal:

- give kommuner og andre aktører med ansvar for levering af tjenester på socialområdet i Norden et forum, hvor de kan se de bedste løsninger, som er udarbejdede, og bruge disse som inspiration.

- være en værdifuld anledning til at fremvise vores mest innovative løsninger og dermed gøre det muligt for offentlige organisationer og filantropiske fonde at støtte videreudviklingen og eventuelt senere fremme eksport af nye løsninger.

- gøre social innovation mere synlig og gøre det klart for resten af verden, at de nordiske lande er engagerede i at udvikle den nordiske velfærdsmodel og opretholde deres stærke position i international sammenligning.

\section{FORSLAG 5: SOCIALE INVESTERINGER OG FOREBYGGELSE}

Vores systemer har ofte ikke de fornødne modeller eller incitamenter til at opfordre til langsigtede investeringer i socialpolitiske løsninger - snarere tværtimod. Der er mange forskellige aktører, som må bidrage til effektive løsninger, og indsatserne er ikke altid koordinerede eller i tilstrækkelig grad fokuseret på brugerens behov. Administrative silostrukturer er en fælles udfordring i alle landene og fører ofte til vanskeligheder ved at arbejde med løsninger på tværs af disse siloer. 
Vi anerkender ikke i tilstrækkelig grad behovet for at investere i sociale indsatser. Måske skyldes det, at vi ikke i tilstrækkelig grad har dokumenteret, hvordan en effektiv social indsats tidligt i den enkelte borgers liv kan skabe besparelser senere. Det er relativt nemt at måle en stigning $i$ antallet af operationer på et hospital og det deraf følgende fald i ventelisterne eller det antal dage, som patienterne er sygemeldt, mens de venter på en operation. Der findes oversigter, der gør det muligt at sammenligne udgifterne pr. studerende på forskellige studier i de nordiske lande, udgifterne til forskellige hospitalsbehandlinger, prisen for at bygge en ny lejlighed, og hvad det koster at videreuddanne en person. Det kan omvendt være sværere med den politiske og administrative forståelse, når det handler om investeringer $\mathrm{i}$ løsninger, der på langt sigt kan reducere marginalisering af voksne eller holde børn og unge i aktivitet og forhindre, at de får psykiske problemer eller et misbrug. Samtidig måles succes på socialområdet generelt forholdsvis kortsigtet, mens løsninger på vor tids komplekse samfundsmæssige udfordringer kræver målrettede løsninger, som måske først giver resultater om flere år. Det er i denne sammenhæng interessant at tænke på, at man i arbejdet med udviklingslande anerkender nødvendigheden af at måle succes på en helt anden tidsskala - for eksempel 4-7 år - som er langt bedre egnet til at måle samfundsmæssige tiltags succes.

Det er også vigtigt, at vores incitamentsstrukturer skaber pres på de forskellige aktører om at bidrage til løsninger. Hvis vores sundheds-, uddannelses-, bolig- og arbejdsmarkedssystemer fungerede perfekt, ville vi have færre socialpolitiske udfordringer. Institutioner inden for disse områder har ofte ikke tilstrækkeligt økonomisk incitament til at tilbyde målrettet støtte. Når en person, der har behov for støtte, er ude af skolesystemet, sparer skolen ressourcer. Når en arbejdsløs vurderes ikke længere at være arbejdsduelig og flyttes fra arbejdsløshedsydelse til førtidspension, er der penge at spare for det system, der udbetaler arbejdsløshedsydelser. Men helhedsomkostningen for samfundet af "udenforskab" bliver ikke nødvendigvis taget med i beregningen. Der kan desuden være en tendens til, at det er de personer, der har de rigtige forudsætninger for at passe ind i løsninger, som får tilbudt løsningerne for på den måde at sikre målopfyldelse, vagtet at personer med ringere forudsætninger tabes. Dette diskuteres videre under forslag 6 om brugerfokus.

De nordiske lande, som generelt tilbyder effektive løsninger inden for de forskellige sektorer, kan gøre meget mere for at skabe sammenhæng mellem forskellige sektorers indsatser for borgere, der også har et socialt støttebehov. Dette er en opfattelse, som aktørerne inden for området deler på tværs af alle landene. Incitamentsstrukturen må i højre grad målrettes til at få forskellige velfærdsområder til at samarbejde om at løse komplekse problemer. Hvis den enkelte borger har behov for støtte fra flere sektorområder, kan det fortsat ofte føles, som om der mangler koordinerede, målrettede tiltag, som hjælper vedkommende med at komme på sporet igen.

Problemet bliver endnu mere akut, når man tænker på, at de, der rent faktisk kan anspore til succes ved at gribe ind i rette tid, som regel ikke er dem, der kan spare penge på at gøre det. I mange tilfælde er det kommunernes sociale myndighed, der har de bedste forudsætninger for at tage initiativ til en tidlig, forebyggende indsats. Men de besparelser, man opnår, optræder ikke altid i det kommunale budget på socialområdet, men derimod i andre sektorområders budgetter eller i det regionale eller statslige budget. Hvorfor skulle kommunernes socialforvaltninger bruge deres knappe ressourcer på at investere i at udvikle og levere løsninger til problemer, som i sidste ende ikke er deres økonomiske hovedpine? 


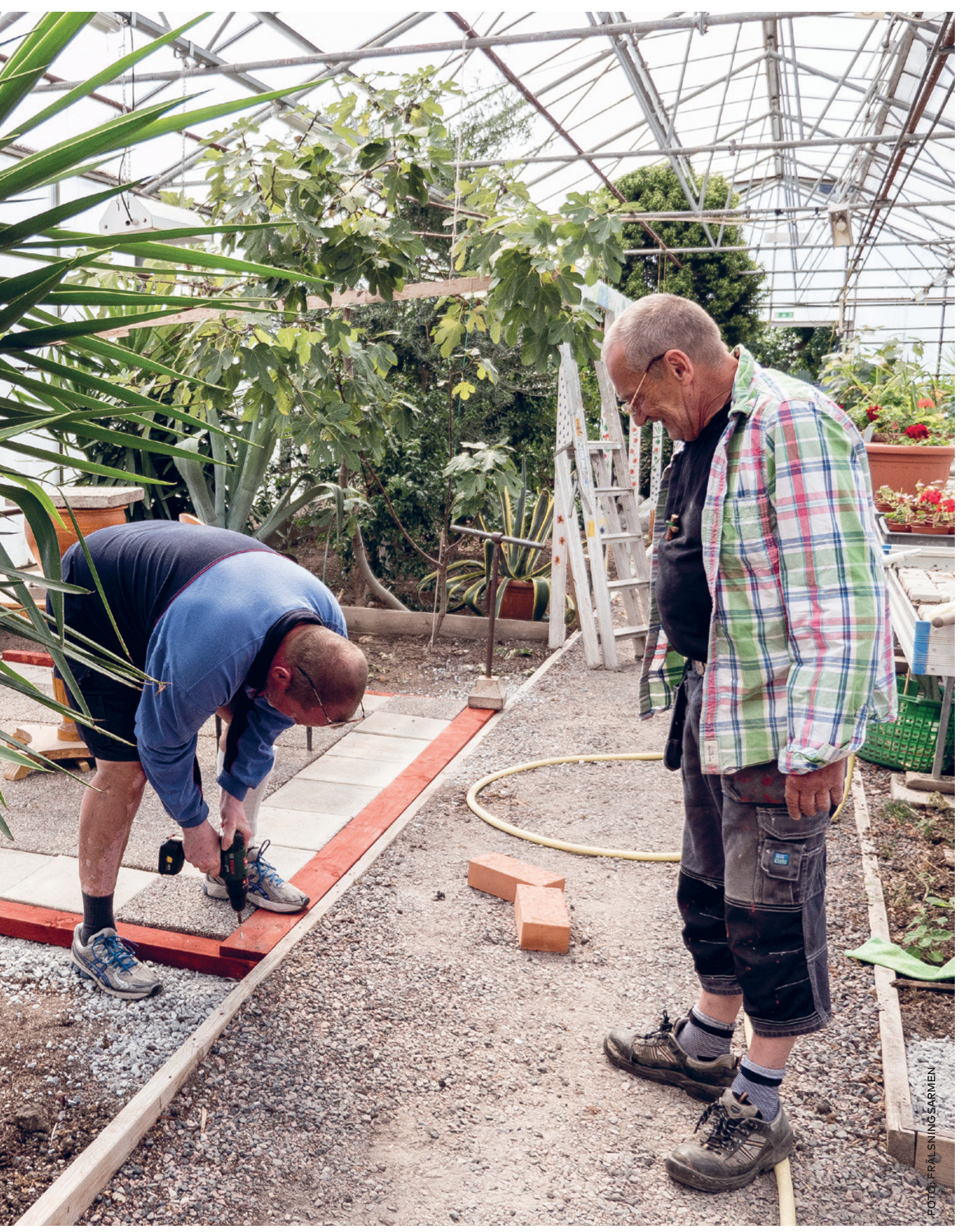


I mange af de nordiske lande er der eksempler på innovative forsøg på at løse dette. Den nye Socialøkonomiske Investeringsmodel (SØM), som er udviklet og for nyligt lanceret i Danmark, giver mulighed for at adressere dette problem. Det samme gælder Idéer för livet-modellen, som Skandia Idéer för livet anvender i Sverige, og fornyelsesinitiativer hos Sitra-innovationscenteret i Finland. Det danske arbejde med oprettelse af Den Sociale Investeringsfond er endnu et eksempel. Over hele verden søger man også løsninger. Gennem Social Impact Bonds har man for eksempel udarbejdet et økonomisk instrument til at få private investorer til at yde finansiering. I Norden bør der være et meget stærkere og mere målrettet fokus på disse problemstillinger.

Det foreslås derfor, at Nordisk Ministerråd for Social- og Helsepolitik drøfter forskellige modeller for incitamentsstrukturer, som fremmer investeringer i tidlige, forebyggende sociale indsatser eventuelt med involvering af Nordisk Ministerråd for Økonomi- og Finanspolitik. Drøftelserne i Nordisk Ministerråd for Social- og Helsepolitik kunne omfatte:

- Erfaringsudveksling om etablering af mekanismer, der fremmer sociale investeringer. Inspiration til dette kan hentes fra de tidligere nævnte eksempler eller nordiske projekter. Et projekt om sociale investeringer kunne udformes på en sådan måde, at både kommuner og frivillige organisationer kan medvirke med deres erfaringer med at udarbejde løsninger, som er ressourceeffektive i forhold til de offentlige budgetter og giver de frivillige organisationer anerkendelse som troværdige og kompetente partnere. Det er også vigtigt at granske strukturen for finansiering af uddannelse, sundhed, bolig og arbejdsmarked. Det skal ikke være "dyrt" at levere løsninger og "gratis" at lade være med at komme med løsningsforslag. Institutioner bør få en økonomisk belønning for at bekæmpe social isolation og udarbejde individuelle løsninger, og det må koste dem noget ikke at bidrage til løsninger.

Derudover foreslås der nordiske samarbejdsinitiativer om metoder til måling af tidlige sociale indsatsers omkostninger og langsigtede, forebyggende sociale og økonomiske effekter. Der kan tages afsæt i de mange eksisterende initiativer i landene.

\section{FORSLAG 6: SOCIALE INDSATSER MED FOKUS PÅ BRUGEREN}

I dag kan den enkelte borger opleve, at det sociale system og reglerne på det sociale område er uoverskuelige og komplekse, og at systemet ikke er centreret om borgeren, men mere er producentorienteret og struktureret omkring tjenesteudbyderne. Der kan også opleves en siloopdeling mellem forskellige sektorer, og at tilbud fra forskellige myndigheder til den samme borger kan virke ukoordinerede. Samlet kan dette betyde, at tilbuddene opleves som standardløsninger, der ikke i tilstrækkelig grad tager højde for, at der kan være brug for forskellige løsninger afhængigt af det enkelte menneskes situation. Mennesker med komplekse problemer bevæger sig ofte mellem flere sektorer i det offentlige system og med flere sagsbehandlere og handlingsplaner, hvilket gør, at det kan blive vanskeligt at finde en samlet indsats, der potentielt kan hjælpe vedkommende. I denne henseende henvises til diskussion under forslag 4 om social innovation og forslag 5 om social investering.

Lad os tage det typiske eksempel med et ungt menneske, som ikke er i arbejde eller under uddannelse. Passivitet fører meget ofte til en forværring af mentale problemer eller misbrug. Det kan føre til boligproblemer og gøre det sværere at finde en løsning på en situation, hvor man står uden bolig. Hvor skal vi begynde? Kan vi tilbyde misbrugs- 
behandling uden tilstrækkelig individuel støtte og udsigt til passende uddannelse, som fører til kompetencer og derefter et arbejde? Og hvornår skal man tage fat i det med boligen? Kan en hjemløs forventes at lægge sit misbrug på hylden, hvis der ikke er udsigt til bolig, arbejde eller passende uddannelse? Sager som disse er vanskelige at løse i alle de nordiske lande. Det skyldes blandt andet, at alle involverede aktører er nødt til at forholde sig til kortsigtede budgetter og leve op til kortsigtede resultatbedømmelser, selvom en langsigtet tidshorisont og mere sammentænkte løsninger til den enkelte borger ville give et bedre resultat. Og manglende succes $\mathrm{i}$ indsatsen for den enkelte kan som bekendt have meget store omkostninger for samfundet, hvis det fører til yderligere mentale og fysiske problemer og livslang understøttelse og deraf følgende manglende skatteindtægter. Problemet forstærkes yderligere, når det medtages, at der er sandsynlighed for, at disse sociale udfordringer går i arv til den næste generation.

Men der ses nu et større fokus på, at de sociale tilbud i højere grad skal tage udgangspunkt i brugeren og dennes ønsker og perspektiv. I de seneste årtier har vi for eksempel gjort meget store fremskridt, når det gælder tilbud til mennesker med handicap, og i dag ville ingen kunne finde på at byde den samme ringe grad af indflydelse på tilbud og hjælp, som man gjorde for 30 år siden. Men selvom vi er kommet langt, kan vi blive meget bedre til at inddrage vores brugergrupper, eksempelvis i forhold til ældre, børn, hjemløse og unge uden uddannelse og arbejde.

I denne sammenhæng spiller de frivillige sociale organisationer en vigtig rolle. Der findes masser af gode eksempler på, at frivillige organisationer yder værdifulde sociale indsatser på en fleksibel og brugertilpasset måde. Frivillige organisationer kan bedre end offentlige organisationer trække på og opbygge sociale netværk og kan ofte i endnu højere grad tilbyde løsninger, der er tilpasset den enkeltes behov.

Et klart brugerfokus er en væsentlig forudsætning for, at den sociale indsats opfylder borgernes behov og forventninger, ligesom det er af central betydning set fra et rettighedsperspektiv. Der ligger samtidig et stort innovativt potentiale i at inddrage borgeres og brugerorganisationers perspektiver og ressourcer i udførelse og udvikling af den sociale indsats.

Det nordiske samarbejde på socialområdet kan være ramme om deling og udvikling af viden, som landene kan bruge til at styrke det nationale udviklingsarbejde i forhold til at sætte borgerne i fokus for de sociale indsatser og inddrage borgernes erfaringer og ressourcer. Det foreslås, at der iværksættes nordiske initiativer om forskellige aspekter af brugerfokus og -inddragelse, eksempelvis:

- Udvikling af individuelt tilpasset service, hvor der sættes fokus på større brugerindflydelse ved valg af tilbud.

- Bedre inddragelse af borgerens perspektiv i egen sag og myndighedsafgørelser.

- Organisering af brugercentrede forløb i de sociale indsatser for ældre, mennesker med handicap, udsatte voksne samt børn og unge.

\section{FORSLAG 7: FRIVILLIGE ORGANISATIONER}

De nordiske lande og det nordiske regeringssamarbejde har en lang tradition for tæutte forbindelser med civilsamfundet. Et stærkt og vitalt civilsamfund er en grundpille i det nordiske demokrati og spiller en vigtig rolle i forhold til at give de nordiske borgere mulighed for at kanalisere deres stemmer og interesser uden for de politiske organisationer. Det nordiske samarbejde bygger på folkelig forankring. 


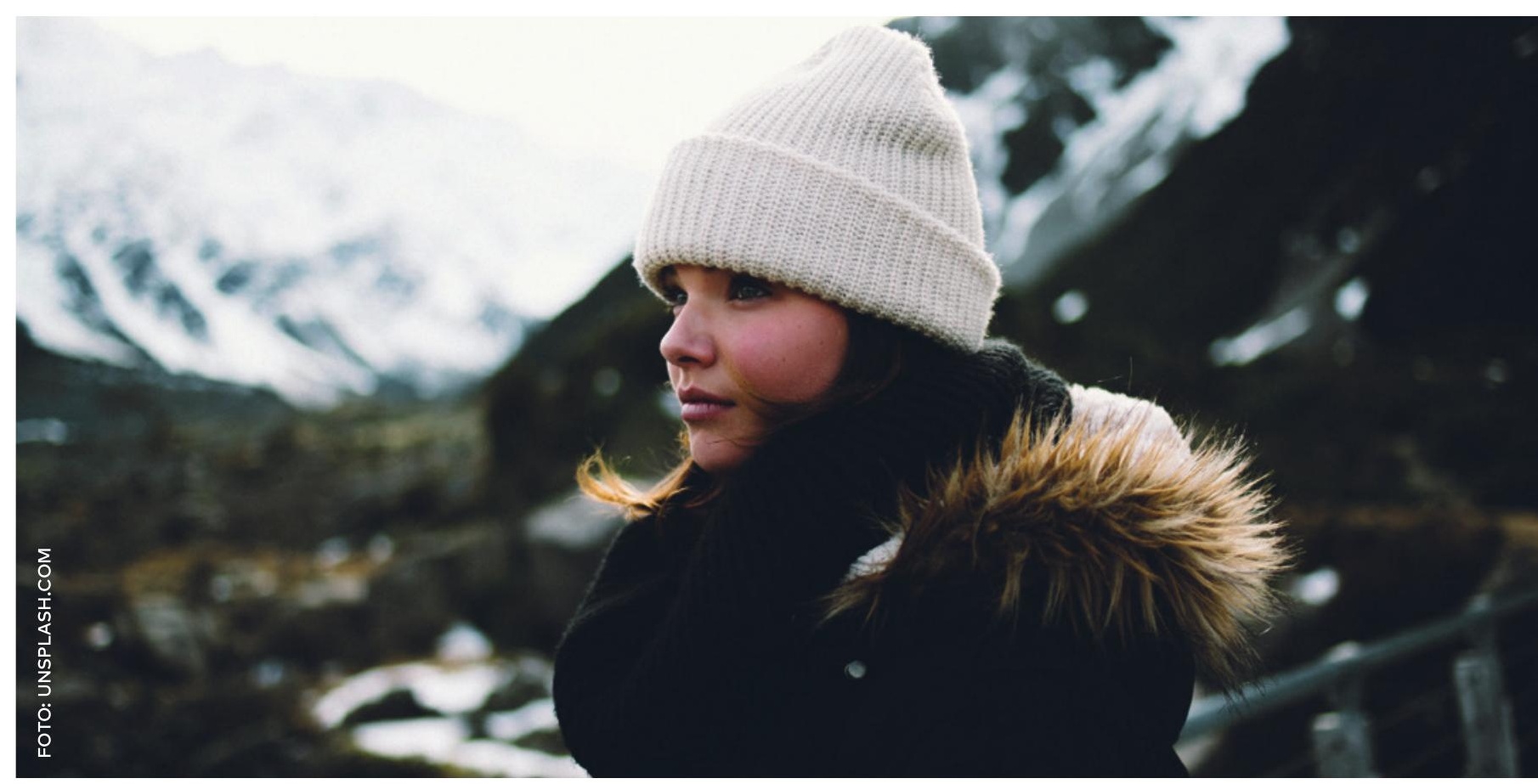

Civilsamfundet bidrager til udviklingen af de nordiske samfund ved at involvere og skabe deltagelsesprocesser for mennesker og bistå med viden og ekspertise. Flere frivillige sociale organisationer har desuden stor betydning som leverandører af sociale tilbud inden for det nordiske velfærdssamfund og har et stort potentiale til at skabe netværk og social kapital. Mange frivillige organisationer bidrager således med tilbud, som det offentlige ikke på samme måde kan levere, for eksempel til mennesker, der befinder sig i en sårbar situation. Organisationerne kan også repræsentere folk i forhold til de offentlige myndigheder, som leverer de fleste af tilbuddene til den enkelte. Mange har også lettere end det offentlige ved at udarbejde individuelle løsninger, fordi der er større fleksibilitet hos den enkelte organisation.

Når vi ser nærmere på de sociale udfordringer, der har størst betydning i dag, er ensomhed, manglende netværk og manglende forbilleder nogle af de temaer, der går igen. Der er mange fordele ved de offentlige sociale tilbud, men de er utilstrækkelige, når det gælder sociale netværk og personlig kontakt. Derfor skal man gøre en systematisk indsats for at styrke alle de sociale netværk i vores samfund: familie, venner, peer-støtte, nabofællesskaber og frivilligt arbejde.

I de nordiske lande er der glimrende eksempler på borgerinitiativer, som bygger bro mellem det offentliges sociale tilbud gennem netværk af frivillige og brugere eller ved hjælp af en kombination af frivillige, fagfolk og brugere. Det er nogle af de mange gode eksempler på social innovation, som vi finder i de nordiske lande. Det er meget vigtigt at udnytte det innovative potentiale, som civilsamfundet kan bidrage med i forhold til at udvikle og levere fleksible, borgerrettede sociale tilbud og dermed bidrage til at udvikle viden og god praksis på socialområdet.

De frivillige organisationer har ikke altid de samme administrative strukturer, som offentlige institu- 


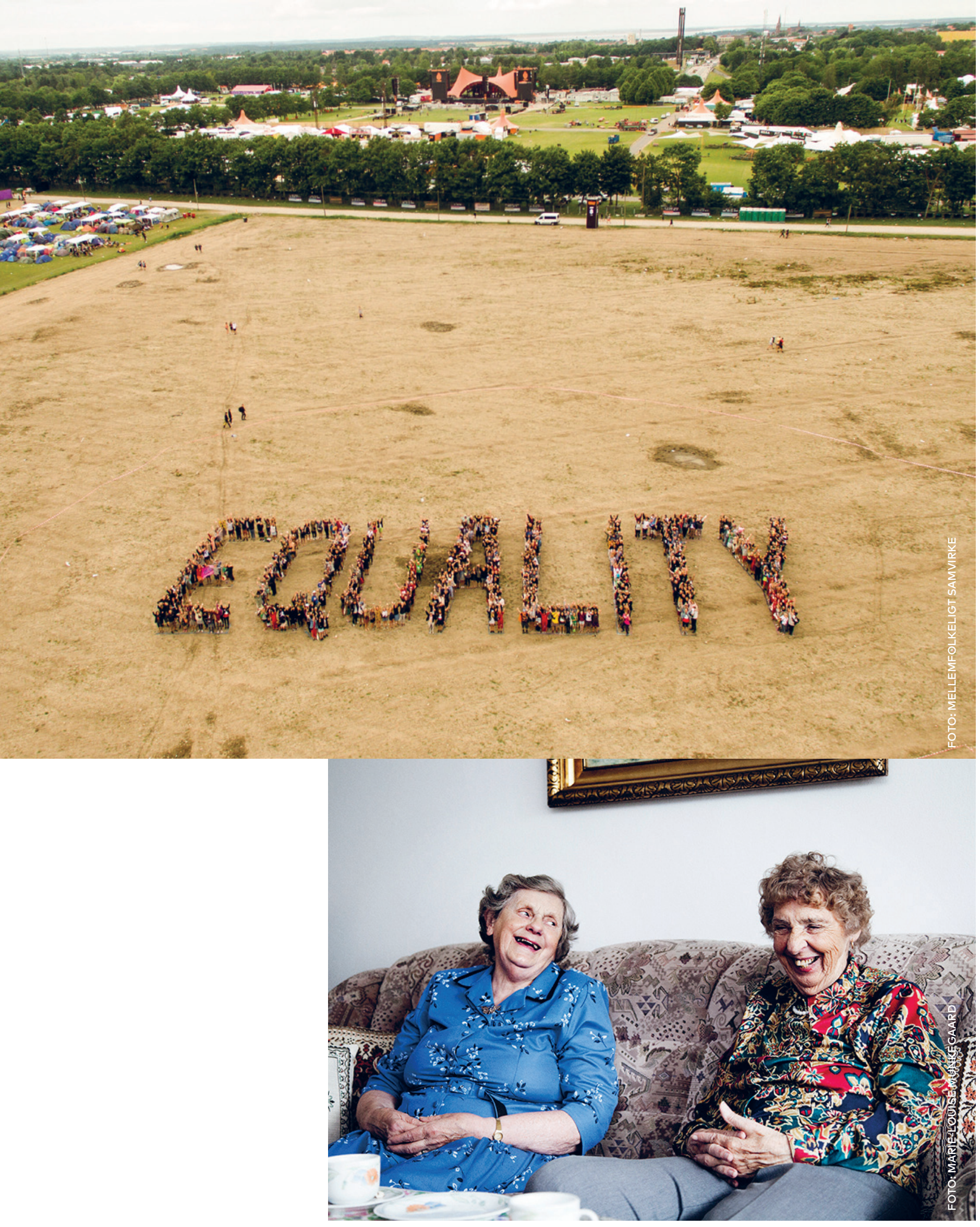


tioner har. Eksempler fra de nordiske lande viser dog, at man godt kan betro civilsamfundet komplekse og ambitiøse opgaver og opnå resultater, som ellers ikke ville have været mulige. Derfor er det vigtigt at udveksle erfaringer om god praksis for, hvordan man indgår aftaler med organisationer i civilsamfundet, betror dem vigtige og ambitiøse opgaver, aflønner dem på en rimelig måde og sørger for realistiske rapporteringskrav, som fokuserer på resultater og ikke formalia.

Det er indtrykket, at der er stor variation i de frivillige organisationer i Nordens indbyrdes kontakt og samarbejde om erfaringsudveksling og videndeling på tværs af landegrænser i Norden. Et vigtigt aspekt er her de ressourcer, som det kræver at deltage i internationalt samarbejde.

I de nordiske lande er der udviklet strategier og indsatser for at fremme samarbejde med civilsamfundet, og hvor det prioriteres at udvikle det aktive medborgerskab og civilsamfundet og understøtte viden og praksis i den frivillige sektor på socialområdet. En nordisk satsning på området skal supplere de nationale initiativer samt styrke de nordiske landes frivillige organisationer i sam- arbejder, der også kan bidrage til at løfte nordiske synspunkter og erfaringer i initiativer uden for Norden.

Det foreslås derfor, at

- de nordiske lande iværksætter initiativer for udveksling af erfaringer om frivillige organisationers medvirken i udvikling og levering af sociale tilbud samt betydningen heraf for kvaliteten af de sociale indsatser samt om gode modeller for, hvordan frivillige organisationer kan få bedre adgang og blive opmuntret til at levere sociale tilbud eller supplere med bidrag til det offentliges tilbud. Et nordisk samarbejde kan også sætte fokus på, hvordan man kan involvere flere borgere i det frivillige arbejde.

- de nordiske lande afsætter midler til en pulje, hvor frivillige organisationer kan søge om midler til for eksempel netværksmøder med henblik på at styrke erfaringsudveksling mellem de nordiske landes frivillige organisationer, at fremme en nordisk stemme i internationale fora samt til at kunne deltage i konferencer i Norden, som er arrangeret af andre frivillige organisationer. 


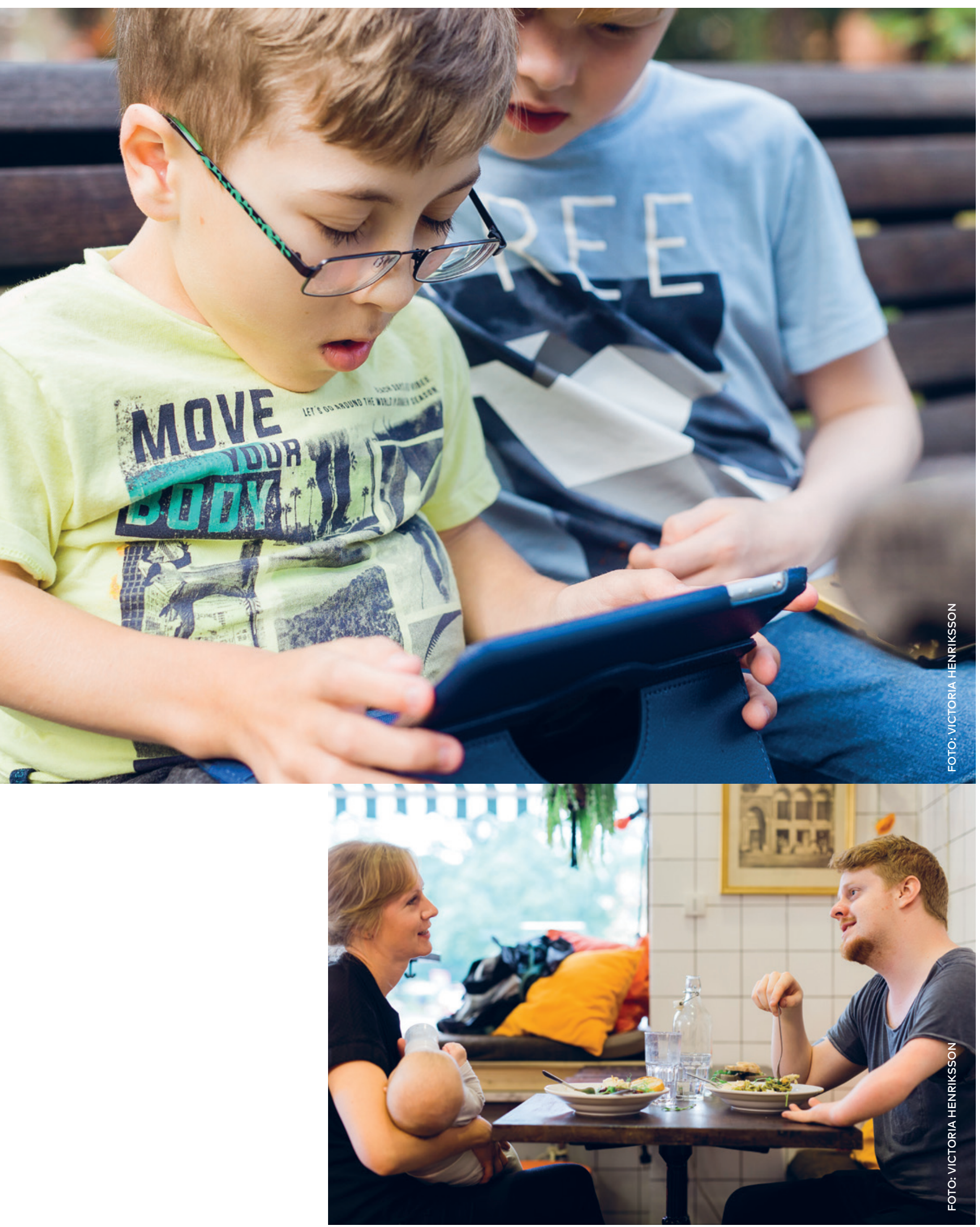




\section{Styrket nordisk samarbejde om børn og unge, udsatte voksne, ældre og mennesker med handicap}

Et mere efterspørgselsorienteret og forstærket nordisk samarbejde på socialområdet med fokus på viden og indsatser, der virker, har som grundlæggende formål at bidrage til at styrke indsatsen for de primære målgrupper på socialområdet, det vil sige udsatte børn og unge, udsatte voksne, ældre og mennesker med handicap. I forbindelse med udarbejdelsen af denne rapport og besøgene i de nordiske lande har der været flere forslag til nordiske initiativer for målgrupperne på socialområdet. Det er helt vomgængeligt, at der er et stort forebyggelsespotentiale i at udvikle virksomme tidlige indsatser for børn og unge. Samtidig medfører de demografiske forskydninger mellem land og by, færre ufaglærte jobs og en tendens til øget mistrivsel i børne- og ungdomsårene en risiko for, at flere marginaliseres i samfundet og bliver socialt udsatte. Den demografiske udvikling i Norden betyder også, at der bliver relativt flere ældre i Norden, som kan få behov for pleje. Dette lægger pres på de nordiske landes velfærdssystemer. Selvom der i regi af Nordisk Ministerråd er et veletableret samarbejde på handicapområdet, kan der til stadighed suppleres med indsatser på dette område.

I det følgende fremgår derfor anbefalinger om styrket nordisk samarbejde om udsatte børn og unge, udsatte voksne, ældre og mennesker med handicap.

\section{FORSLAG 8: UDSATTE BØRN OG UNGE}

De nordiske lande har indrettet sig sådan, at der er gode muligheder for et godt børneliv, der går over i et ungdomsliv, hvor unge mænd og kvinder rustes til fortsat at udvikle sig som mennesker og samfundsborgere. Politiske prioriteringer, dygtige fagpersoner, skoler og børnehaver, NGO'ers indsats og først og fremmest forældrene og børn og unge selv har i et samspil skabt et rum for, at der er fokus på børns rettigheder, trivsel og udviklingsmuligheder.

Til trods for at de nordiske landes tilbud til børn og unge og deres familier generelt er af høj kvalitet, er der dog problemstillinger, som kræver en forstærket indsats. Derfor gennemfører de nordiske lande løbende omfattende udviklingsarbejder for at styrke indsatserne for børn og unge og imødegå aktuelle udfordringer. På børn- og ungeområdet er der i landene gennemført en omfattende opbygning af viden om målgrupper og deres behov samt om virksomme metoder og indsatser.

I det nordiske samarbejde er der blandt andet i regi af social- og sundhedssektoren, uddannelsessektoren og Nordisk Børne- og Ungdomskomité (NORDBUK) gennemført en række nordiske initiativer om børn og unge. Der findes dog et uudnyttet potentiale til i højere grad at anvende det nordiske samarbejde på socialområdet som en arena, hvor de nordiske landes centrale aktører, særligt styrelser/direktorater og sektorforskningsinstitutioner, efter behov kan identificere og igangsætte relevante samarbejdsinitiativer. Det kan eksempelvis være udveksling af viden og erfaringer gennem netværk på udvalgte områder, men muligheder for fælles initiativer til udvikling af viden og afprøvning af metoder bør også undersøges. 
Nedenfor er beskrevet tre temaer, der foreslås som afsæt for videreudvikling af det nordiske samarbejde om børn og unge på socialområdet.

Det foreslås, at der med henblik på at identificere relevante nordiske initiativer arbejdes videre med disse og eventuelt andre områder i regi af det foreslåede Forum for Nordisk Samarbejde på Socialområdet (se forslag 2) eller et andet forum med repræsentation fra landene.

\section{Børns rettigheder}

De sociale myndigheder i de nordiske lande udfører et omfattende arbejde for at hjælpe udsatte børn, der har brug for hjælp. Men inddragelsen af børn, så børnenes ønsker og synspunkter kan indgå ved tilrettelæggelsen af hjælpen, kan stadig styrkes. Det er vigtigt med en løbende kapacitetsopbygning på dette område for at sikre det enkelte barns rettigheder og tilbyde barnet den bedst mulige hjælp.

Det foreslås derfor, at der med afsæt i FN's konvention om barnets rettigheder iværksættes nordiske initiativer om, hvordan myndighederne bedre kan inddrage børn og høre deres synspunkter i deres egne sager. Det uformelle netværk af børneombudsmændsfunktionerne i de nordiske lande kan for eksempel inddrages med henblik på at identificere emner, hvor nordiske initiativer kunne bidrage til landenes arbejde.

\section{Viden om hvad der virker på børneområdet}

De nordiske landes indsatser for udsatte børn har de seneste år været kendetegnet ved en omfattende opbygning af viden om virksomme metoder for børn og familier, der har behov for støtte. Det nordiske samarbejde kan, som foreslået i forslag 1 om systematisk samarbejde om viden om virksomme indsatser, i højere grad blive en platform, hvor landene kan udveksle viden om virksomme indsatser, men potentielt også være en platform for afsøgning af mulighederne for at gennemføre fælles afprøvninger af metoder og forskningsprojekter. Fælles nordiske initiativer om afprøvning af metoder er ambitiøst og vil kræve politisk prioritering og koordinering af ressourcer - ikke bare i det nordiske budget, men også i landene selv.

Det kan derfor overvejes, om samarbejdet på børn- og ungeområdet kunne styrkes ved etablering af et højniveaumøde eller lignende, hvor de relevante direktorater i landene mødes og drøfter temaer og konkrete initiativforslag for nordiske initiativer om børn og unge. Et sådant forum kunne løbende drøfte eksempelvis mulighederne for fælles nordiske afprøvninger af metoder og orientere om aktuelle nationale tiltag. Der bør koordineres i forhold til det eksisterende nordiske initiativ om formidling af viden på børn- og ungeområdet gennem internetportaler, som er igangsat af Nordisk Embedsmandskomité for Social- og Helsepolitik i 2018, og som projektledes af det norske Barne-, ungdoms- og familiedirektorat.

\section{Unge udenfor}

I de nordiske lande er der en voksende gruppe af unge mænd og kvinder, der mistrives og har psykiske problemer. Flere unge er ikke aktive i uddannelse eller på arbejdsmarkedet og står i risiko for et langvarigt "udenforskab", hvilket ofte giver en række sociale og sundhedsmæssige problemer, som kan række langt ind i voksenlivet. Det nordiske samarbejde kunne mere systematisk udveksle erfaringer og udvikle viden om for eksempel:

- Nationale strategier for forebyggelse af marginalisering af unge, herunder orientering om større satsninger og forskningsprojekter, som kunne være relevante på tværs af landene.

- Lettilgængelige rådgivningstilbud til unge, hvor den unge hurtigt kan få hjælp. Der kan i denne sammenhæng også ses på erfaringerne med samarbejde med frivillige organisationer om relevante rådgivningstilbud til unge samt 
på tværsektorielle initiativer, der koordinerer indsatser fra forskellige sektorer (fx social-, uddannelses- og psykiatrisektoren) for unge med komplekse støttebehov.

- Incitamentsstrukturer, der på tværs af offentlige sektorer fremmer en tidlig, forebyggende indsats for unge og modvirker, at den enkelte unge falder mellem forskellige stole, se forslag 5 om social investering og forebyggelse.

- Synliggørelse og inddragelse af unges synspunkter i udviklingen af indsatser og tilbud på området. Der kan eksempelvis søges samarbejde med initiativer såsom det nordiske ungetopmøde med fokus på unges mentale sundhed, som blev afholdt i København i november 2017 med NGO'er fra de nordiske lande, der arbejder med mental sundhed blandt unge.

- Erfaringsudveksling om indsatser for at fremme inklusion af unge mænd og kvinder på uddannelses- og arbejdsmarked i tyndtbefolkede områder (se også forslag 13 om tyndtbefolkede områder).

\section{FORSLAG 9: UDSATTE VOKSNE}

Hjælp og støtte til borgere i en udsat social situation er en af hjørnestenene i de nordiske velfærdssamfund. Det gælder både de, der for en kortere periode i deres liv har brug for hjælp fra samfundet, og de, der af forskellige årsager i en større del af deres liv har brug for samfundets støtte. Det nordiske samarbejde bør bidrage til konkret vidensudvikling og erfaringsudveksling på dette område, men også skabe platforme for løbende diskussioner af, hvordan velfærdssamfundet kan indrettes, så det giver en værdig støtte til de, der har behov.

Arbejdsmarkedstilknytning er omdrejningspunktet for en række indsatser for mennesker i en socialt udsat position. Deltagelse på arbejdsmarkedet giver selvbestemmelse og selvværd og er en vigtig adgang til netværk og samfundsdeltagelse. Men i alle lande ser man grupper, der trods mange forskellige indsatser ikke kommer i beskæftigelse. Det gælder også for flygtninge og indvandrere. En vigtig opgave for den socialpolitiske indsats er at modvirke marginalisering af de, der har lang vej til arbejdsmarkedet. Denne opgave har en væsentligt kønsdimension i de nordiske samfund, hvor kvinder i stigende grad uddannes bedre end mænd, samtidig med at der bliver relativt færre ufaglærte jobs. Et tværsektorielt tiltag i samarbejde med det nordiske samarbejdes ligestillings- og arbejdslivssektorer kunne være et interessant udgangspunkt for afdækning af relevante nordiske samarbejdsinitiativer om udsatte mænds forhold med hensyn til arbejdsmarkeds- og samfundsdeltagelse. Tilsvarende kunne bidrag til det eksisterende nordiske samarbejde om integration, som de nordiske samarbejdsministre har iværksat, være relevant i forhold til at sætte fokus på forebyggelse af social udsathed hos nyankomne, der endnu ikke har fået fodfæste i de nordiske samfund.

Det er vigtigt, at mennesker i en socialt udsat situation har en stærk stemme i diskussionen og udformningen af de socialpolitiske tiltag, som omfatter dem selv. Her løfter de frivillige sociale organisationer en væsentlig opgave, og det er et arbejde, der med fordel kunne fremmes med afsæt i det nordiske samarbejde. De frivillige organisationer i de nordiske lande, der har udsatte voksne som sin målgruppe, samarbejder i varierende grad, for eksempel er der et samarbejde i relation til European Anti Poverty Network. Men nordisk og internationalt samarbejde kræver ressourcer, og det kan være en udfordring for organisationerne at finde midler til at deltage heri. Den foreslåede pulje til støtte til nordisk samarbejde mellem frivillige organisationer, som indgår i forslag 7, vil kunne støtte civilsamfundets samarbejde på området for udsatte voksne på tværs af Norden. 
Nordisk samarbejde om at styrke indsatsen for socialt udsatte og forebyggelse af marginalisering bør desuden ses i sammenhæng med en række af de øvrige forslag i denne rapport. Det foreslåede samarbejde om bolig- og socialpolitik i forslag 12 har som to af de foreslåede temaer boliger til socialt udsatte og hjemløse samt boligsociale indsatser i almennyttige og kooperative boligområder. Endvidere bør udvikling af viden om effektive indsatser for socialt udsatte løftes i et forstærket nordisk samarbejde om viden, som beskrives i forslag 1. OECD's projekt om Faces of Joblessness: Understanding employment barriers to inform policy, som nævnes under forslag 14 om internationalt samarbejde, kunne også være relevant som inspiration for det nordiske samarbejde med udsatte voksne og deres tilknytning til arbejdsmarkedet.

\section{FORSLAG 10: AELDRE}

Indbyggerne i Norden lever længere, og det betyder, at andelen af ældre øges. I et globalt perspektiv lever man relativt længe i Norden og længere end gennemsnittet for både EU og USA. Selvom mange ældre er friske og klarer sig fint, og at det er positivt, at flere lever længere, indebærer det også nogle udfordringer, eftersom de nordiske samfundsudgifter til ældreomsorgen øges. Flere ældre vil på længere sigt have behov for hjælp og omsorg. Fokus vokser således på ressourcerne til ældreomsorg, andre måder at tilrettelægge omsorgen på og kvaliteten heraf samt rekruttering af plejepersonale til at arbejde i ældresektoren, når der bliver flere ældre og færre i arbejdsstyrken.

Den demografiske udvikling betyder, at i takt med at flere og flere bosætter sig i de større byer i Norden, vil det være den ældre befolkning, der bliver tilbage. Det giver udfordringer i forhold til at tilrettelægge en god og effektiv pleje, og hertil kommer risikoen for større ensomhed og isolering $\mathrm{i}$ samfund, hvor mange flytter væk. Derfor er ældre- området også relevant i forhold til det foreslåede samarbejde, der indgår i forslag 13 om tyndtbefolkede områder.

På ældreområdet står de nordiske lande således over for de samme udfordringer. Det vil derfor være oplagt at øge samarbejdet vedrørende udfordringerne på ældreområdet i forhold til bedre kvalitet og anvendelsen af rehabilitering, brugen af velfærdsteknologi og hele problemstillingen med at rekruttere personale til ældresektoren i fremtiden.

Både i og uden for EU er ældreområdet i fokus. Et af mange eksempler er WHO's netværk Age-friendly cities and communities, hvor byer fra Norden deltager. Norden er på mange måder langt fremme i forhold til resten af verden, når det gælder ældreområdet - både i forhold til omsorg, velfærdsteknologi og inklusion. Der er et godt potentiale i Norden for at udvikle området mere, både i nordisk regi og internationalt.

Nordisk Ministerråd for Social- og Helsepolitik har valgt at prioritere området som et politisk tema for 2019-2021 under overskriften "Hur skapar vi mer sammanhållna vård- och omsorgsprocesser, med särskild fokus på äldre brukare och patienter". I nordisk regi foregår der derudover flere aktiviteter på ældreområdet om blandt andet velfærdsteknologi, nordisk demensnetværk og udvikling af aldersvenlige byer. Det er vigtigt, at dette arbejde fastholdes, styrkes og videreudvikles i nordisk regi, så det nordiske samarbejde kan bidrage til at møde udfordringerne med de demografiske ændringer og dermed en voksende ældrebefolkning.

Det foreslås, at Nordisk Ministerråd for Socialog Helsepolitik ser på, hvordan det eksisterende samarbejde i nordisk regi på ældreområdet kan udvikles yderligere, så nye, relevante temaer indgår i samarbejdet. 


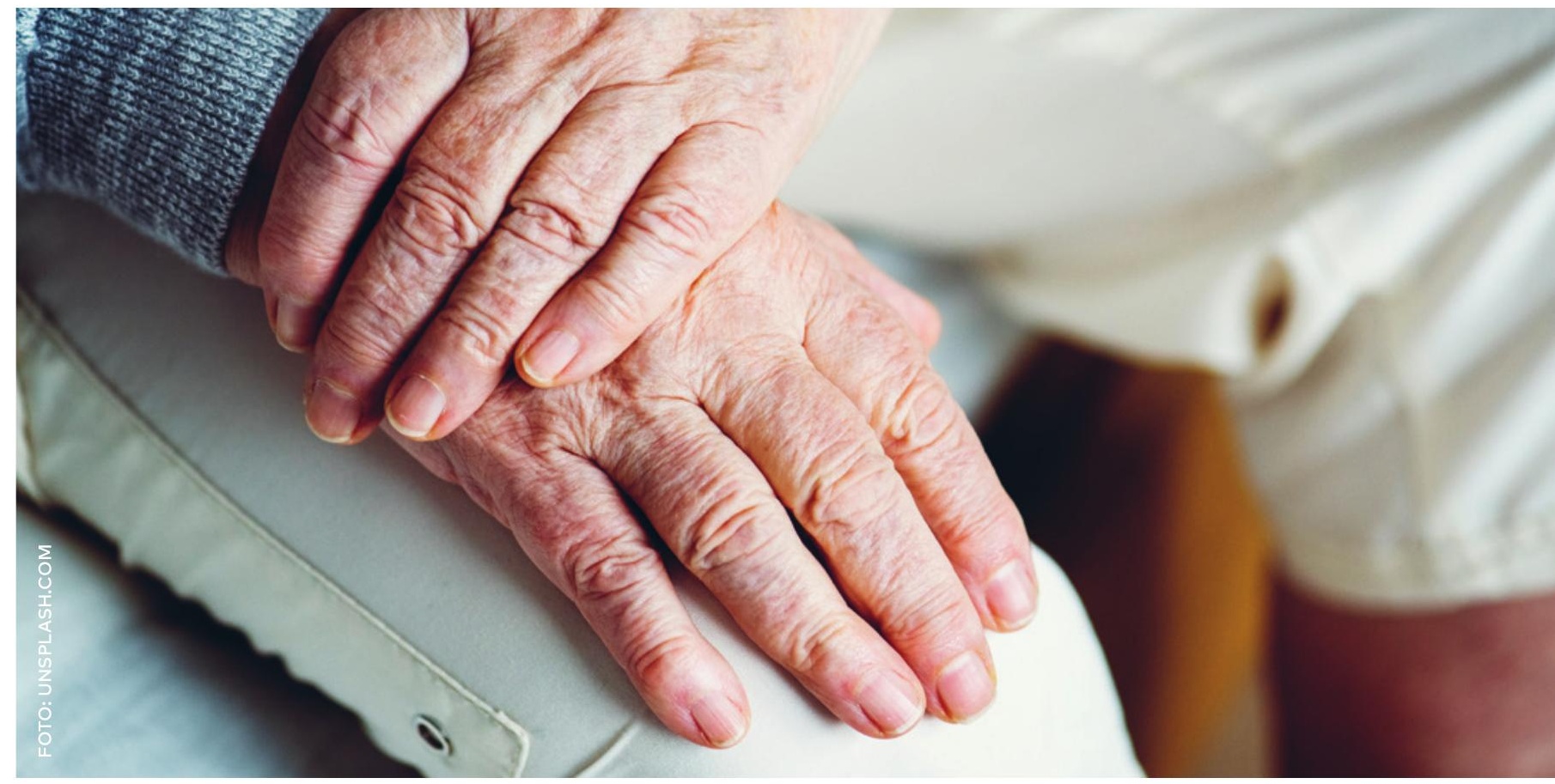

I de nordiske lande er der stort fokus på rehabilitering og indsatser, som har til formål, at ældre kan opretholde et selvstændigt, meningsfuldt og selvhjulpent liv, hvor man ser på den ældres livssituation som en helhed. Det foreslås derfor, at der i det nordiske samarbejde sættes fokus på vidensdeling og erfaringsudveksling mellem landene om rehabilitering inden for ældreområdet.

Hvad angår boliger til ældre, vil det i et nordisk perspektiv være interessant at se nærmere på mere fleksible boligformer til ældre og deres behov. Et intensiveret nordisk samarbejde på boligområdet, som foreslået i forslag 12, kan desuden have som ambition at gøre det mere attraktivt at bygge billigere boliger til forskellige målgrupper, herunder ældre.

Det foreslås desuden, at der etableres et fælles nordisk initiativ om udveksling af viden og erfaringer med virksomme nationale og lokale tiltag til rekruttering af medarbejdere til omsorgs- og plejesektoren, herunder idéer til nye tiltag. Der kan blandt andet sættes særligt fokus på opkvalificering, fastholdelse af medarbejdere i landdistrikter samt veje til rekruttering af flere mænd til pleje- og omsorgsjobs. I den forbindelse bør der ses på tilrettelæggelsen af arbejdet i ældreplejen, herunder hvordan man kan gøre ældreplejen som arbejdsplads mere attraktiv for både mænd og kvinder at arbejde i.

\section{FORSLAG 11: MENNESKER MED HANDICAP}

Det nordiske samarbejde på handicapområdet er velfungerende og forholdsvis omfattende og består først og fremmest af tre værktøjer: Rådet for nordisk samarbejde om handicap (Funktionshinderrådet), som er et rådgivende organ for hele det officielle nordiske samarbejde, Nordisk Ministerråds tværsektorielle handlingsplan på handicapområdet med fokus på menneskerettigheder, holdbar udvikling og fri bevægelse samt Nordens Velfærdscenter, som er sekretariat for Funktionshinderrådet, og som desuden administrerer en 
støtteordning, der fremmer nordisk samarbejde mellem handicaporganisationerne.

Handicappolitikken bidrager til et bæredygtigt samfund, hvor ingen lades udenfor, og målsætningen er inkludering af mennesker med handicap på alle samfundets områder. Den demografiske udvikling med en aldrende befolkning i Norden indebærer også flere ældre mennesker med en funktionsnedsættelse. Politikken på handicapområdet præges mere og mere af rettighedsperspektivet, som får et globalt udtryk i FN's konvention om menneskerettigheder for personer med funktionsnedsættelser, UNCRPD. Samtlige lande i Norden har ratificeret konventionen.

\section{Tilgængelighed}

Et centralt element $i$ at fremme inklusion af mennesker med handicap er arbejdet for øget tilgængelighed i samfundet. Det nordiske samarbejde kan supplere det nationale arbejde på feltet, herunder ved at bygge videre på det arbejde, der allerede udføres i relation til Funktionshinderrådet. Samarbejde kræver en indsats fra flere politiksektorer. Her skal peges på tre aspekter i forbindelse med tilgængelighed og brugerinddragelse, som ville være relevante for et styrket nordisk samarbejde på området.

Tilgængelighed i forhold til bolig

Boligen har stor betydning for den enkelte borgers liv og velfærd. For borgere med et handicap er det særligt vigtigt, at egen bolig er tilgængelig, men tilgængelighed er også et vigtigt aspekt i forhold til at have adgang til andre boliger og offentlige bygninger. Forslag 12 vedrørende bolig- og socialpolitik inddrager også dette aspekt i ønsket om et større nordisk samarbejde på boligområdet eksempelvis i forhold til standarder for tilgængelighed og universelt design samt om boliger til mennesker med handicap.
Tilknytning til arbejdsmarkedet

Mennesker med handicap kan, selvom de gerne vil arbejde, ofte have sværere ved at finde fodfæste på arbejdsmarkedet og dermed deltage i arbejdslivet. Det bør derfor i samarbejde med arbejdslivssektoren i nordisk regi drøftes, hvordan man kan bidrage med tiltag, der kan få flere i denne gruppe i arbejde. Nye teknologiske muligheder og løsninger bør være et vigtigt aspekt i disse tiltag.

Frivillige organisationers medvirken i arbejdet med tilgængelighed

Frivillige organisationer spiller en vigtig rolle med deres ekspertise og erfaringer $i$ at opbygge et samfund, som er tilgængeligt for alle, og også som fortalere for mennesker med et handicap. Det er derfor vigtigt, at disse organisationer medvirker i nordiske samarbejdsprojekter på området. Her henvises til forslagene 6 og 7 om henholdsvis styrkelse af brugerfokus samt styrkelse af nordisk samarbejde vedrørende frivillige organisationer.

\section{Sjældne handicap}

Inden for sjældne handicap har man gode erfaringer med at drage nytte af samarbejde på tværs af landegrænser. Landene deltager i samarbejde i regi af EU, og Nordisk Ministerråd har etableret et nordisk netværk om sjældne sygdomme, som omfatter indsatser på både social- og sundhedsområdet, og som har deltagelse fra myndigheder, kompetencecentre og brugerorganisationer.

Givet at målgrupperne inden for feltet sjældne handicap er små, kan "stordriftsfordelene" ved at etablere fælles nordiske initiativer være store med hensyn til muligheden for at udvikle viden og skabe større fagmiljøer gennem netværk af specialister og fagfolk, der går på tværs af de nordiske landes grænser. Et godt eksempel på dette er det nordiske samarbejde om døvblinde, som understøttes af Nordens Velfærdscenter. I lyset af forslag 1 om systematisk samarbejde om viden på det sociale område foreslås det at afdække, hvordan det 


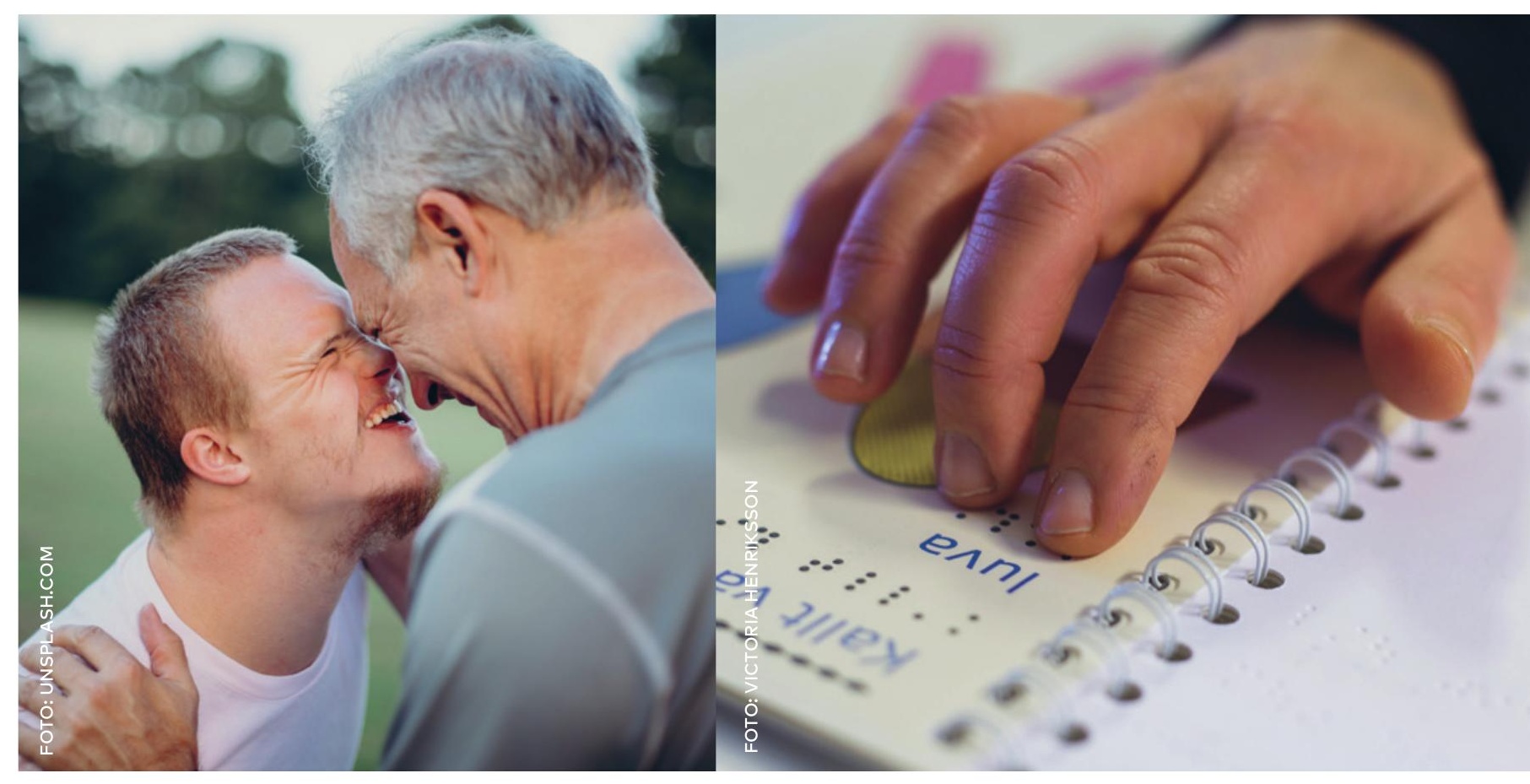

nordiske samarbejde i højere grad kan koordinere systematisk samarbejde om udvikling af viden på området for sjældne handicap, herunder også gennem facilitering af samarbejde mellem specialister i landene. En vigtig gruppe her er børn med sjældne handicap. En ny nordisk indsats bør koordineres i forhold til det eksisterende nordiske netværk om sjældne sygdomme.

\section{Uddannelse}

I Handlingsplan for nordisk samarbejde om handicap 2018-2022 er indsatser, der kan styrke viden og dialogen om menneskerettigheder, et fokusområde. Det foreslås i forlængelse heraf, at der ses nærmere på mulighederne for nordisk samarbejde om uddannelse i relation til handicapområdet. I Funktionshinderrådets regi er der allerede overvejelser om dette, blandt andet i forhold til programmerne Nordplus og Nordic Master.

For at fremme disse overvejelser foreslås det, at der tages initiativ til et nordisk seminarium med relevante aktører fra uddannelsesinstitutionerne og handicapområdet med henblik på at drøfte behovet for et tættere uddannelsessamarbejde på handicapområdet i nordisk regi. 

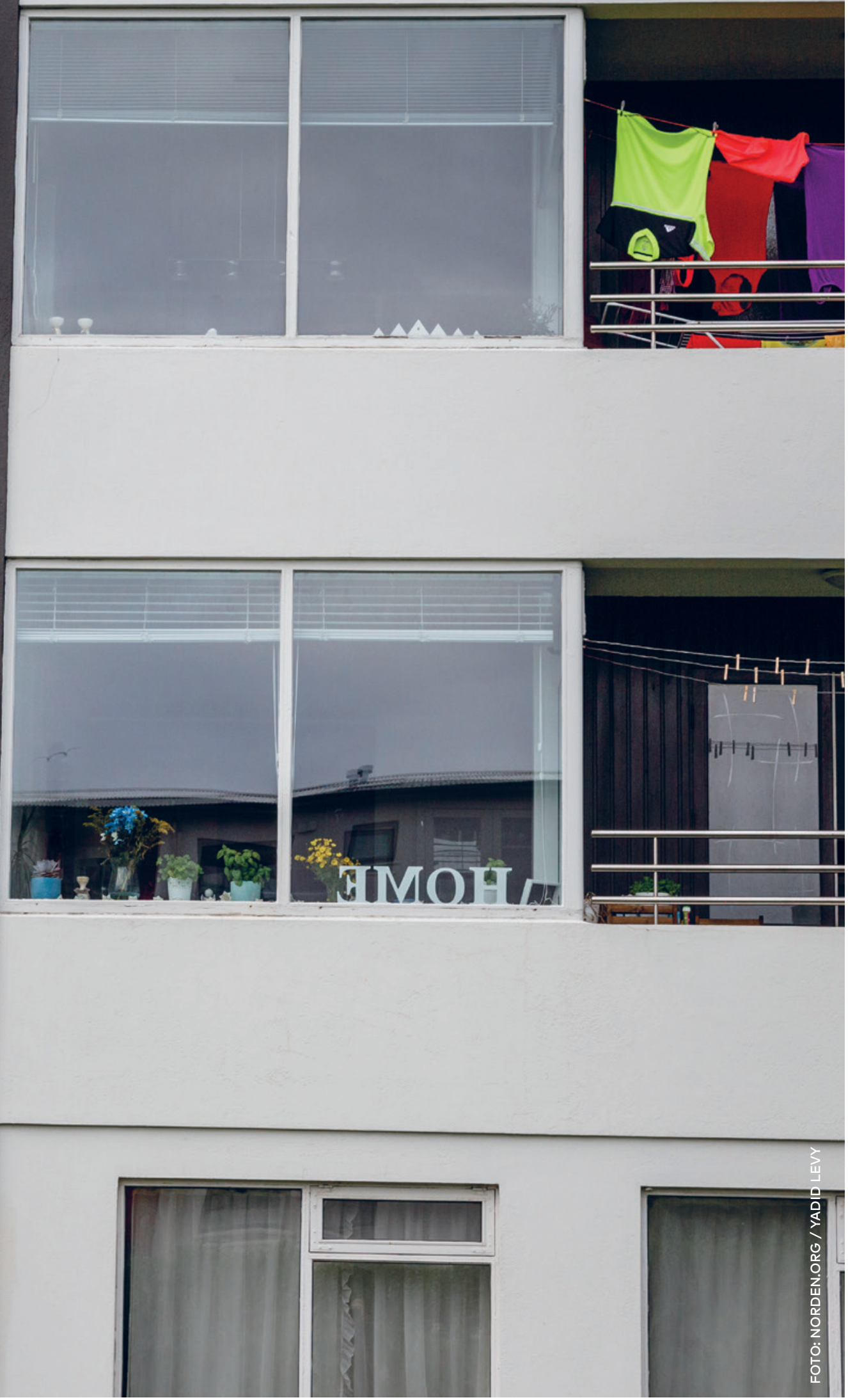


\section{Sociale indsatser i et bredere perspektiv}

Ved besøgene i de nordiske lande i forbindelse med udarbejdelsen af denne rapport blev det flere gange nævnt, at både boligområdet og den nordiske geografi med mange tyndtbefolkede regioner var med til at give særlige udfordringer på socialområdet. På boligområdet oplever de nordiske lande stigende boligpriser især i byområderne, som gør det svært for flere borgere at finde en bolig, der er til at betale, ligesom der ikke altid er den fornødne fleksibilitet i boligformerne, når det for eksempel gælder boliger til ældre og mennesker med et handicap. Norden udgør en stor geografisk region med mange tyndtbefolkede områder. Som i mange andre lande uden for Norden sker der i flere af disse områder en afvandring af mennesker til mere bymæssige områder. Det giver udfordringer i forhold til at kunne opretholde et højt socialt serviceniveau i disse mere tyndtbefolkede egne.

Denne del af rapporten indeholder derfor forslag til at styrke det nordiske samarbejde, når det gælder bolig- og socialområdet samt til at styrke det nordiske samarbejde om de særlige problemstillinger på socialområdet i tyndtbefolkede områder.

Mange lande uden for Norden skeler på socialområdet til den nordiske velfærdsmodel og de nordiske velfærdsløsninger for at få inspiration til nye sociale løsninger. Men Norden kan også hente ny viden uden for Norden. Profilering af Norden og nordiske velfærdsløsninger uden for Norden og i forskellige internationale fora handler både om at gøre opmærksom på den nordiske velfærdsmodel og om at hente viden og inspiration i mødet med andre samfundsløsninger. Derfor afsluttes der med forslag til at styrke det nordiske samarbejde på det internationale område.

\section{FORSLAG 12: BOLIG- OG SOCIALPOLITIK}

Boligen er en væsentlig del af rammen om den enkelte borgers liv, og adgangen til en passende bolig har stor betydning for den enkeltes trivsel og adgang til samfundsdeltagelse. Det gælder for borgere generelt og i særdeleshed for borgere med behov for støtte, hvor eksempelvis ældre, mennesker med handicap og udsatte grupper ofte har særlige behov i relation til boligen.

De nordiske lande oplever den samme tendens til, at det i flere byer er blevet sværere at få en bolig, som er til at betale. I nogle byer, særligt hovedstæderne, er der boligmangel. Målrettet byudvikling har gjort mange bymiljøer mere indbydende, men bagsiden af medaljen i mange af de større byer er, at en stadig større del af den boligmasse, der var tilgængelig for personer med en lav eller moderat indkomst, er blevet bygget om eller renoveret, så personer med lavere indkomster ikke har råd til dem.

Boligforhold og boligpolitik er relevante i forhold til indsatser på det sociale område. Men boligpolitisk samarbejde i regi af Nordisk Ministerråd har været stort set fraværende, og der er et uudnyttet potentiale i at samarbejde om eksempelvis udveksling af erfaringer og om konkrete initiativer. Et nyt nordisk tiltag på området er imidlertid bolig- og byggeministrenes møde den 29. maj 2018, hvor ministrene erklærede, at de vil fremme et styrket og integreret marked for byggeri i Norden. 


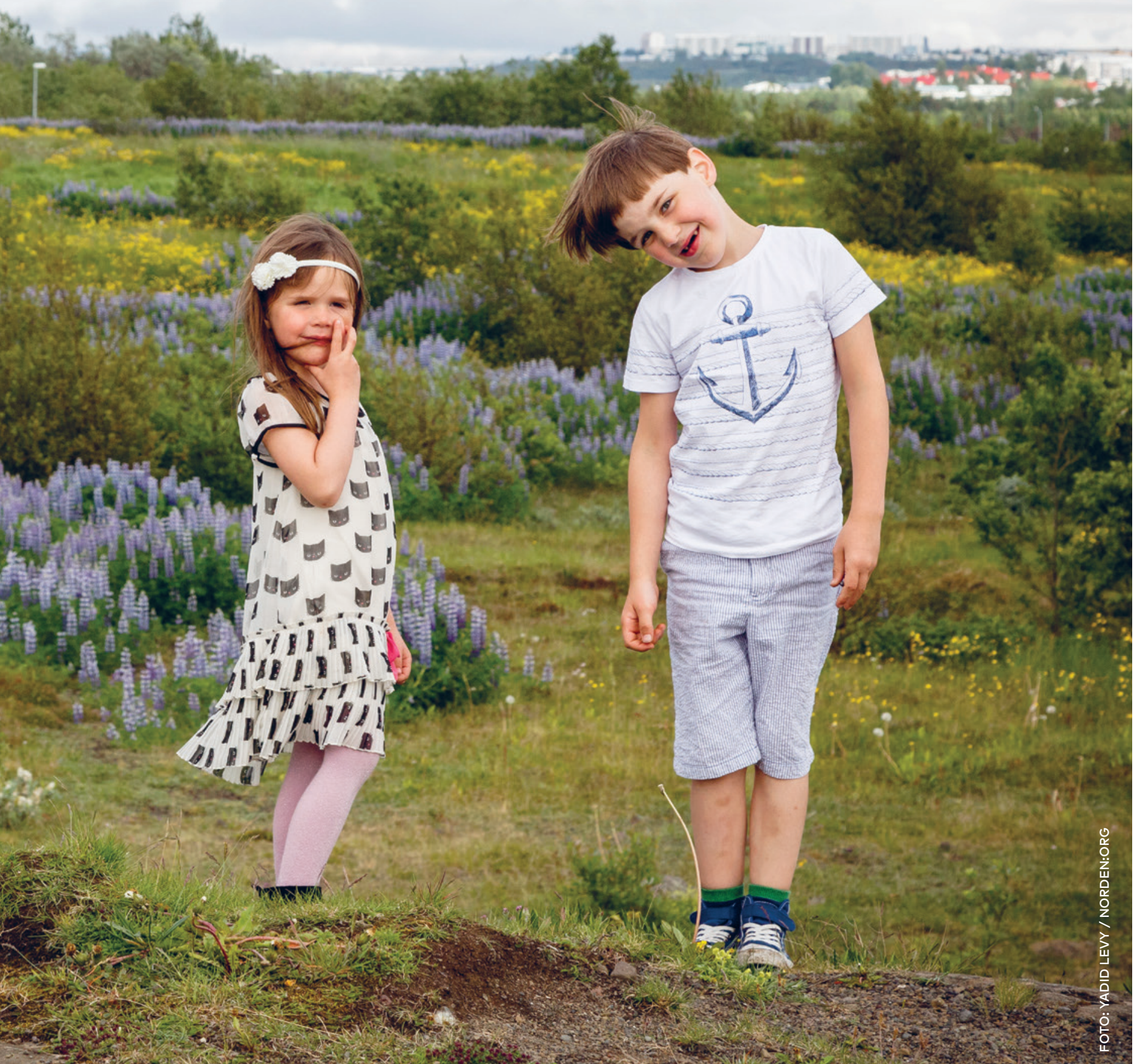


Det foreslås derfor, at der i regi af Nordisk Ministerråd etableres et tværsektorielt samarbejde mellem de nordiske social- og boligministre med henblik på, at ministrene sammen med relevante aktører i Norden drøfter udviklingen på boligområdet i de nordiske lande i relation til socialpolitiske målsætninger og løbende identificerer muligheder for et nordisk samarbejde på boligområdet, som også kan have relevans i forhold til andre sektorområder i det nordiske samarbejde, fx energi-, klima- og erhvervsområdet samt det nordiske samarbejde vedrørende FN's verdensmål. I et nyt samarbejde på boligområdet kan der desuden sættes fokus på potentialerne for nordiske initiativer, der kan medføre lavere byggeomkostninger gennem mere ensartede byggestandarder for tilgængelighed og universelt design.

Et nordisk samarbejde om boligområdet bør inddrage relevante aktører på boligområdet i landene og give mulighed for en bred debat og erfaringsudveksling om, hvordan boligmæssige tiltag kan bidrage til at fremme de socialpolitiske målsætninger i landene. Eksempelvis har de nordiske landes boligselskaber etableret et samarbejde i regi af den nordiske forening NBO - Housing Nordic, som blandt andet er en ramme for udveksling af erfaringer og samarbejde på det kooperative og almennyttige boligområde blandt NBO's medlemmer, som tæller Danmark, Finland, Island, Norge og Sverige. NBO - Housing Nordic og andre centrale aktører, der arbejder med boligrelaterede forhold, kan med fordel inddrages aktivt i et nordisk social- og boligpolitisk samarbejde. For eksempel udarbejder NBO hvert andet år en rapport, der giver et samlet overblik over udvikling, trends og udfordringer på det nordiske boligmarked i de nordiske lande. Rapporten indeholder også konkrete anbefalinger, som vil kunne indgå i drøftelser i Nordisk Ministerråd. Den seneste rapport blev præsenteret på en konference i Stockholm i august 2018.
Samlet foreslås det, at der etableres et samarbejde mellem de nordiske bolig-og socialministre, som gennem eksempelvis ministerkonferencer, højniveaumøder og konkrete initiativer iværksætter nordiske boligpolitiske initiativer med relevans for socialområdet. I et nordisk samarbejde kunne der drøftes forskellige temaer såsom:

- Den generelle udvikling på boligområdet set i lyset af sociale forhold, der giver de nordiske lande styrkepositioner eller udfordringer, eksempelvis med afsæt i den årlige rapport fra NBO - Housing Nordic.

- Erfaringsudveksling om, hvordan ikke-markedsbaserede løsninger kan adressere manglen på boliger.

- Inkluderende byer med varierede boligtilbud og plads til alle.

- Kortlægning af årsagerne til de høje byggeomkostninger i Norden og mulige løsninger.

- Boligsociale indsatser i almennyttige og kooperative boligområder.

- Fælles nordiske standarder for tilgængelighed og universelt design i forhold til boliger.

- Nye boligformer til ældre, eksempelvis bofællesskaber.

- Boliger til mennesker med handicap, socialt udsatte og hjemløse.

Flere af temaerne har ud over deres relevans for bolig- og socialområdet også tråde til andre sektorområder, for eksempel energi-, klima- og erhvervsområdet samt bolig- og byggeministrenes samarbejde.

\section{FORSLAG 13: TYNDTBEFOLKEDE OMRÅDER}

Norden omfatter et stort geografisk område, hvor der er mange tyndtbefolkede regioner. Disse områder tilfører Norden en stor kulturel og naturmæssig rigdom og besidder store menneskelige ressourcer. En række strukturelle tendenser i de nordiske samfund har imidlertid betydning for de sociale levevilkår for mennesker i disse områder. 
Den demografiske udvikling indebærer, at flere områder er præget af en aldrende befolkning og affolkning, blandt andet på grund af færre uddannelses- og beskæftigelsesmuligheder.

Der er en række ganske konkrete udfordringer i forhold til at levere sociale tjenester i både tilstrækkelig omfang og af høj kvalitet i tyndtbefolkede områder. Der kan eksempelvis være større udfordringer forbundet med, inden for de tilgængelige ressourcer, at levere pleje og omsorg til ældre og tilbud til børn, socialt udsatte og mennesker med handicap i områder, hvor der er store geografiske afstande og en lille befolkning. Relevante problemstillinger er her for eksempel rekruttering af medarbejdere og opretholdelse af faglige miljøer med det nødvendige vidensniveau. Herudover er det i et socialpolitisk perspektiv vigtigt at modvirke, at ændrede strukturelle vilkår resulterer i en øget risiko for marginalisering af mænd og kvinder, som bor og vokser op i mindre samfund.

Det foreslås, at det nordiske samarbejde iværksætter initiativer med det formål at udveksle og udvikle viden om, hvordan sociale tjenester på en ressourceeffektiv måde kan leveres i det fornødne omfang og kvalitet i tyndtbefolkede områder. Det foreslås også, at der iværksættes initiativer om, hvordan der sikres gode vilkår for uddannelse, arbejde og samfundsdeltagelse for drenge og piger og unge mænd og kvinder, der vokser op i tyndtbefolkede områder.

Der kan overvejes forskellige typer initiativer, eksempelvis:

- Samarbejde om social innovation med særligt fokus på sociale tilbud i tyndtbefolkede områder, eksempelvis gennem brug af mobile tjenester, velfærdsteknologi og digitalisering.

- Udveksling af erfaringer om organisering af sociale tilbud i tyndtbefolkede områder, herunder for eksempel samarbejde på tværs af administrative enheder og samarbejde på socialområdet i tyndtbefolkede grænseregioner mellem de nordiske lande.

- Udveksling af erfaringer fra landenes indsatser om rekruttering og opkvalificering af personale i tyndtbefolkede områder.

- Erfaringsudveksling om indsatser til fremme af inklusion af unge mænd og kvinder på uddannelser og arbejdsmarked i tyndtbefolkede områder (se også forslag 8 om børn og unge).

- Fremme opretholdelse og dannelse af fællesskaber i tyndtbefolkede områder gennem frivillige organisationers indsats. Der kan eksempelvis etableres nordiske netværk eller platforme mellem frivillige organisationer, kommunesammenslutninger og nationale myndigheder, der kan give inspiration til lokale og regionale indsatser på området.

\section{FORSLAG 14: DET INTERNATIONALE SAMARBEJDE}

Nordisk Ministerråd for Social- og Helsepolitik har i sit samarbejdsprogram sat fokus på at fremme samarbejdet om EU-spørgsmål af fælles nordisk interesse, hvor det er relevant i forhold til EU's tidlige lovgivnings- og beslutningsfase for EU-Kommissionens fremsættelse af forslag samt den senere implementering af EU-lovgivning på social-og sundhedsområdet.

Der er heller ikke nogen tvivl om, at der hos EU-Kommissionen og i OECD er stor interesse for den nordiske velfærdsmodel og de nordiske sociale systemer, og at der er fokus på det sociale område i bred forstand.

Flere af de aktiviteter og initiativer, som Nordisk Ministerråd for Social- og Helsepolitik har iværksat eller gennemført på socialområdet har også en europæisk eller international dimension. Det gælder for eksempel handicapområdet, hvor 


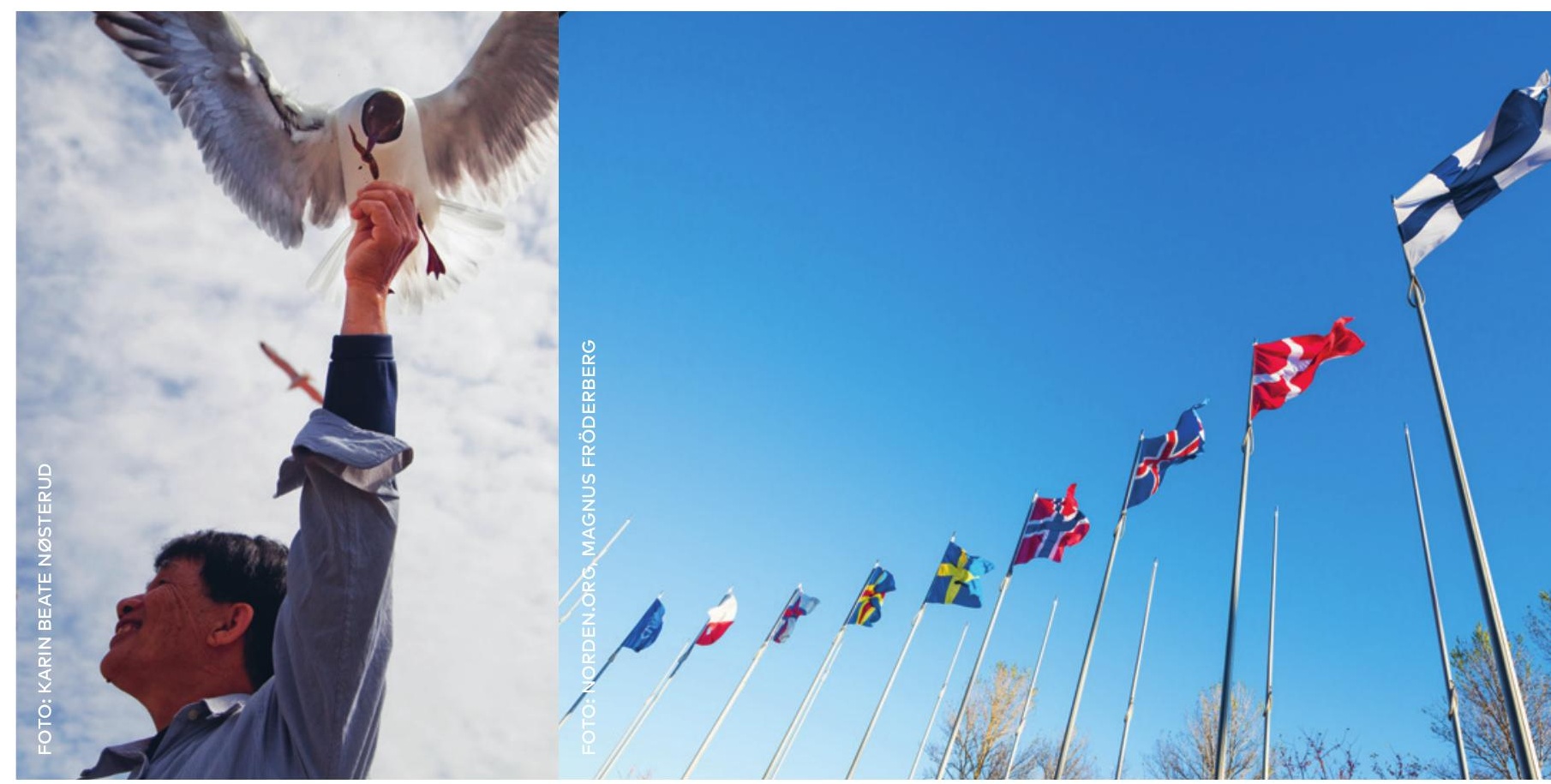

fx FN's handicapkonvention er et vigtigt fundament for arbejdet i Rådet for Nordisk Samarbejde om Handicap. Et andet eksempel er Europa-

Parlamentets- og Rådets forordning (EF)

Nr. 883/2004 om koordinering af medlemslandenes socialsikringssystemer. Her foregår der et stort arbejde mellem de nordiske lande i forhold til ændringer i forordningen og tolkning af bestemmelser. Dette foregår dels i Den Administrative Kommission for Koordinering af Socialsikringssystemer, som er etableret med hjemmel i forordning 883/2004, dels i Nordisk socialforsikringsgruppe, som har sit mandat fra Nordisk Ministerråd for Social- og Helsepolitik.

Socialområdet har fået stigende betydning $\mathrm{i}$ EU-samarbejdet, og EU-samarbejdet er ganske omfattende på socialområdet, selvom området i overvejende grad er præget af national kompetence. Det sociale område berører direkte borgernes leve- og livsvilkår, og kompetencespørgsmål mellem national- og EU-kompetence er en til stadighed aktuel diskussion i EU-regi på dette område.

Det foreslås derfor, at Nordisk Ministerråd for Social- og Helsepolitik i højere grad udnytter sit samarbejde til at inddrage, indhente og drøfte relevant viden fra EU og de internationale organisationer, som beskæftiger sig med socialområdet, og sætte fokus på den nordiske koordinering $\mathrm{i}$ forbindelse med møder eller andre aktiviteter for at fremme nordiske synspunkter i disse fora, når det gælder socialområdet. Samtidig bør der også være fokus på, hvad Norden kan bidrage med af gode erfaringer og nye måder og metoder, som både kan styrke profileringen af Norden på socialområdet og medvirke til at værne om den nordiske velfærdsmodel. Samarbejdet kan med fordel tage udgangspunkt $i$ konkrete emner eller forslag. Et eksempel kunne være OECD's projekt om Faces of Joblessness: Understanding employment barriers to inform policy, som også vil have relevans i arbejdet med udsatte voksne og deres tilknytning 
til arbejdsmarkedet, jf. forslag 9. Den europæiske søjle for sociale rettigheder vil sætte fornyet fokus på den europæiske sociale dimension og vil derigennem kunne udmønte sig i nye EU-retsakter, som det vil være aktuelt at samarbejde om på nordisk niveau. Et tredje eksempel kunne være implementeringen af EU's tilgængelighedsdirektiv. Endelig kunne det overvejes at tage EU-Kommissionens årlige landespecifikke henstillinger op i Nordisk Ministerråd for Social- og Helsepolitik med det formål at holde tæt kontakt og støtte hinanden i at bevare og forklare den nordiske velfærdsmodel. Det er ikke kun relevant for de tre nordiske lande, der er medlem af EU, men også for de andre to, som i stort omfang implementerer EU-retsakter på socialområdet på grund af EØS-aftalen.
Endelig foreslås det, at der i de nordiske initiativer på socialområdet generelt kommer et større fokus på viden fra lande uden for Norden og fra internationale organisationer, herunder især EU, OECD og FN-organisationerne. De nordiske initiativer på socialområdet har oftest først og fremmest sigte på, at de nordiske lande skal lære af hinanden. Dette er fortsat meget relevant, men samtidig vurderes det, at det nordiske samarbejde ofte også vil kunne bruges som en fælles base til at hente state of the art-viden på socialområdet ved at vende blikket udad. 

Nordisk Ministerråd

Norden Hus

Ved Stranden 18

1061 København K

www.norden.org

Nordisk Ministerråd for Social- og Helsepolitik (MR-S) besluttede i 2017 at gennemføre en strategisk gennemlysning af det nordiske samarbejde på socialområdet. Formålet var at udvikle og styrke det nordiske samarbejde på socialområdet, så det er tilpasset landenes behov og aktuelle problemstillinger samt fører til konkrete resultater. Gennemlysningen skulle resultere i en rapport med forslag, som MR-S og Embedsmandskomitéen for Socialog Helsepolitik (EK-S) kan anvende til at udvikle både det eksisterende samarbejde og nye initiativer i et tidsperspektiv på 5-10 år.

Gennemlysningen er udført af tidligere socialminister og økonomiminister i Island, Árni Páll Árnason, som på baggrund af konsultationer med aktører på socialområdet i og uden for Norden har udarbejdet en uafhængig rapport med 14 forslag til, hvordan det nordiske samarbejde på socialområdet kan styrkes.

Denne rapport er en del af en serie af strategiske og fremadrettede undersøgelser i Nordisk Ministerråd. De tidligere undersøgelser, såkaldte strategiske gennemlysninger, omhandler arbejdsliv, miljø, lovgivning, sundhed og energi. Gennemlysningerne er tilknyttet reformarbejdet Nyt Norden i ministerrådet. 